\title{
ANALOG MODEL ANALYSIS OF THE NORTH COAST LIMESTONE AQUIFERS, PUERTO RICO
}

\section{U.S. GEOLOGICAL SURVEY}

OPEN-FILE REPORT 82-52

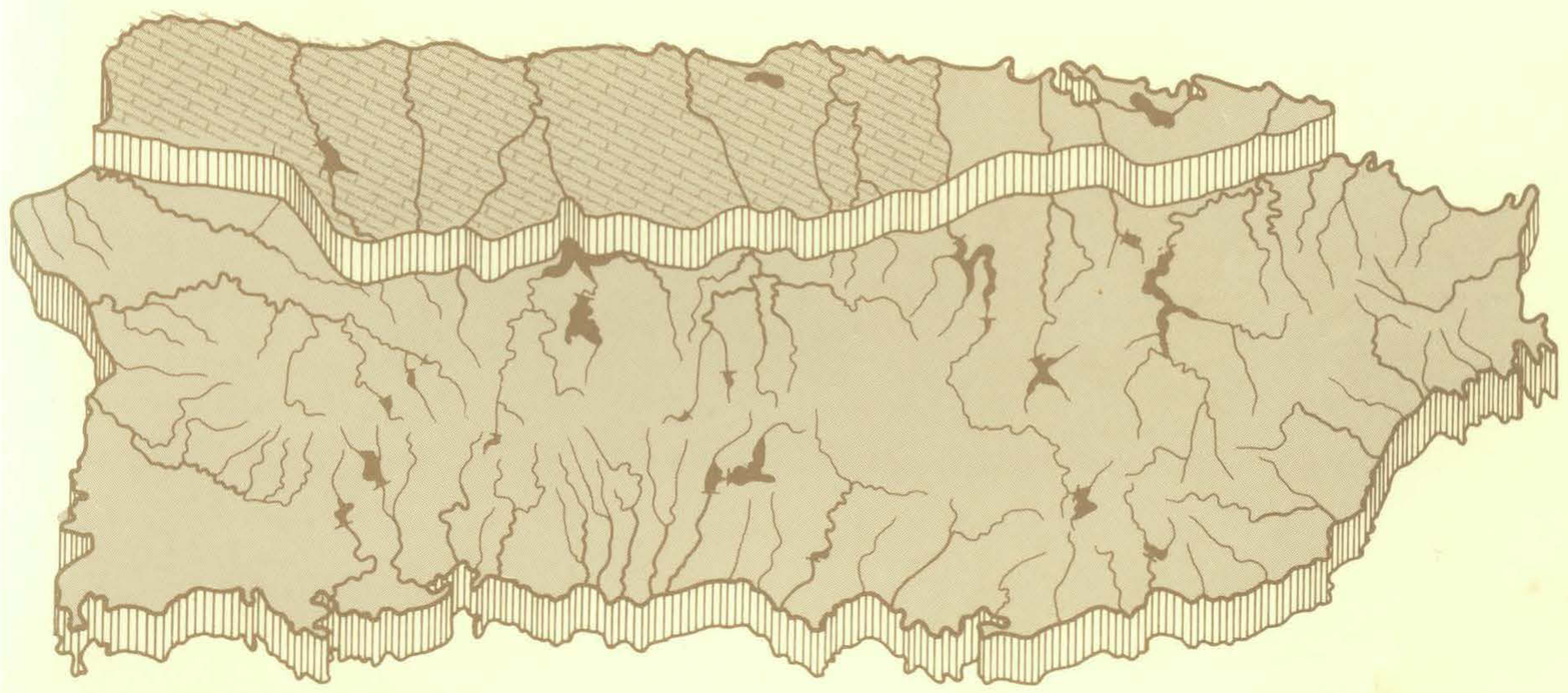

Prepared in cooperation with the:

PUERTO RICO ENVIRONMENTAL QUALITY BOARD AND PUERTO RICO DEPARTMENT OF NATURAL RESOURCES

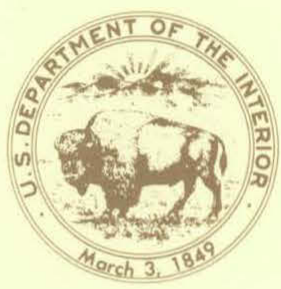




\section{ANALOG MODEL ANALYSIS OF THE NORTH COAST LIMESTONE AQUIFERS, PUERTO RICO}

By James E. Heisel, José R. González, and Carlos Cruz

U.S. GEOLOGICAL SURVEY

OPEN-FILE REPORT 82-52

Prepared in cooperation with the:

PUERTO RICO ENVIRONMENTAL QUALITY BOARD AND PUERTO RICO DEPARTMENT OF NATURAL RESOURCES

San Juan, Puerto Rico

1983 


\section{UNITED STATES DEPARTMENT OF THE INTERIOR}

JAMES G. WATT, Secretary

\section{GEOLOGICAL SURVEY}

Dallas L. Peck, Director

For additional information write to:

Chief, Caribbean District, WRD

U.S. Geological Survey

GPO BOX 4424

San Juan, Puerto Rico 00936

(Telephone: $(809)$ 753-4414)
Copies of this report can be purchased from:

Open-File Services Section Western Distribution Branch U.S. Geological Survey Box 25425, Federal Center Denver,Colorado 80225 (Telephone: (303) 234-5888) 
Abstract......................................

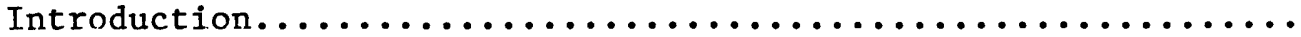

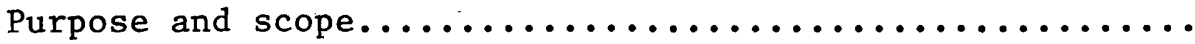

Acknowledgements.............................

Study area.................................

Climate.................................

Geology .....................................

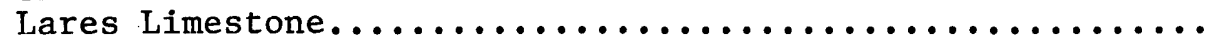

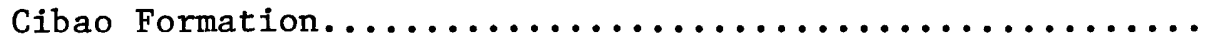

Aguada Limestone............................

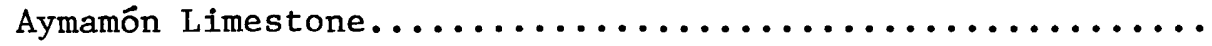

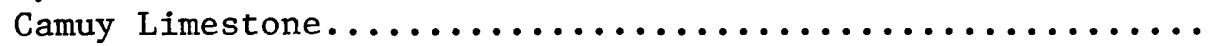

Hydrology ....................................

Ground Water..............................

Water-table aquifer.......................

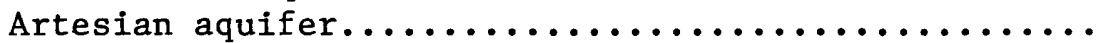

Ground water-surface relationships.................

Regionalization of aquifer characteristics for modeling...

Transmissivity.........................

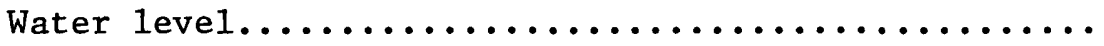

Recharge and storage coefficients...............

Discharge.............................

Aquifer boundaries.........................

Broad upward leakage.....................

Model design and characteristics.....................

Hardware..................................

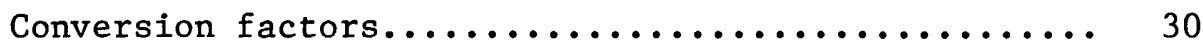

Model verification.......................... 31

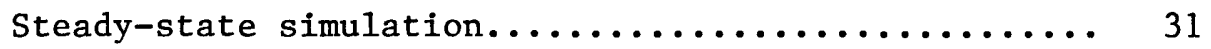

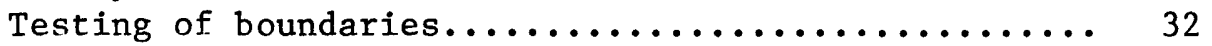

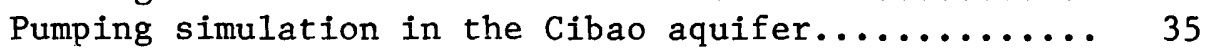

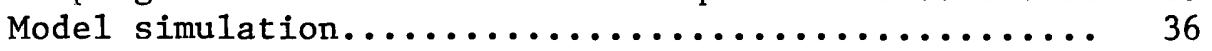

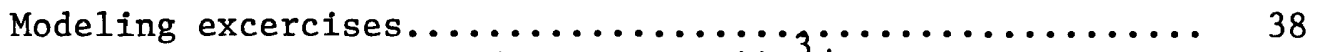

Simulation of Withdrawal of $0.44 \mathrm{~m}^{3} / \mathrm{s}$ from the water-Table Aquifer............... 39

Simulation of long-term withdrawal from the water-table aquifer.................. 39

Simulation of increased withdrawal from the Cibao Formation..................... 41

Conclusions................................... 43

Selected references................................ 47 


\section{ILLUSTRATIONS}

Page

Figure 1. Map showing area of investigation.............. 3

2. Map showing outcrops of limestone in the north coast study area, Puerto Rico........ 8

3. Map showing pumping rates and estimated transmissivity values at study area test wells, in the water-table aquifer......... 9

4. Map showing location of artesian wells in the Cruce Dávila area.................... 11

5. Graphs showing water-level declines in artesian aquifer, Cruce Dávila area, Puerto Rico. Adjustment to common datum by adding wellhead elevation to hydrostatic pressure... 13

6. Map showing estimated transmissivity variation in in the water-table aquifer............ 17

7. Map showing transmissivity as modeled in the Cibao Formation...................... 18

8. Map showing transmissivity as modeled in the Lares Limestone ........................ 19

9. Map showing water-table elevations in the north

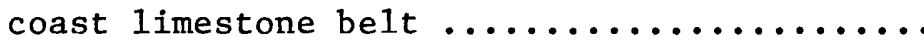

10. Map showing location of streamflow stations and other data collection points (after Giusti

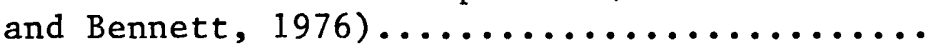

11. Diagram showing graphical method of determining recharge from observation-well records.......

12. Bar, chart illustrating variation of average monthly precipitation and estimated recharge, study area I, north central Puerto Rico.......... 25

13. Map showing simulated recharge and discharge areas... 27

14. Diagram showing schematic of the connections within a circuit unit of 8 nodes.............

15. Map showing simulated water-levels for mode1

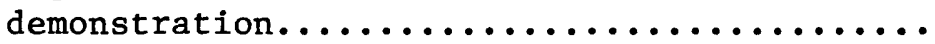

16. Map showing water-level change resulting from simulated pumping an additional $0.44 \mathrm{~m}^{3} / \mathrm{s}$

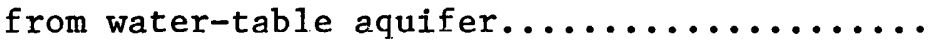

17. Map illustrating simulated drawhdown for long-term water withdrawal $1.6 \mathrm{~m} / \mathrm{s} \ldots \ldots \ldots \ldots \ldots \ldots$.

18. Map showing simulated water-level changes after pumping $0.44 \mathrm{~m} / \mathrm{s}$ for 90 years from the

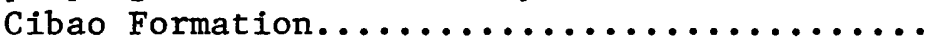

19. Map showing simulated water-level changes after Pumping $0.44 \mathrm{~m} / \mathrm{s}$ for 160 years from the

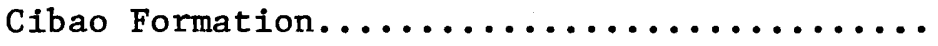




\section{TABLES}

Page

Table 1. Estimated transmissivities of artesian wells in the

Cruce Dávila area, Puerto Rico............

2. General characteristics of artesian aquifer outcropping across the north coast limestone

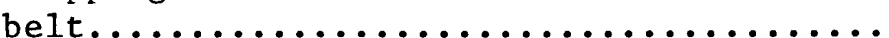

3. Recharge values for subareas of the north coast limestone belt, in millimeters for the period November 1969 to October $1970 \ldots . .21$

4. Average monthly recharge, Sabana Hoyos we11........ 24

5. Ground-water flow from discharge areas............ 31

6. Summary of simulated recharge values for steady-

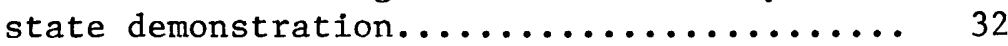

7. Simulated discharge values for steady-state

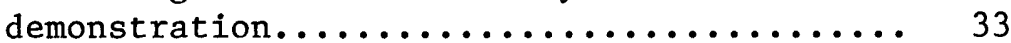

8. Cibao aquifer pumping simulation data........... 35

\section{ACKNOWLEDGMENT}

Edit. Aset. \& Typing Carmen A. Garcla

Drafting and Art...............José Allcea and Gllberto Poha Report Reviow............Fordinend Qulhones and Allen Zeck 


\section{CONVERSION TABLE}

Area, volume and flow values are given in metric units (SI) in this report. SI units may be converted to inch-pound units using the following factors. Multiply the SI unit by the factor to find the inch-pound unit.

\section{Length}

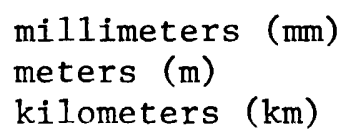

Hydraulic Conductivity

meters per day (m/d)

meters squared per day $\left(\mathrm{m}^{2} / \mathrm{d}\right)$
0.003937
3.281
0.6215

$\underline{\text { Area }}$

0.3863

Volume

35.31

Flow

35.31

22.82

15.85
Hydraulic Conductivity

\section{$\underline{\text { Transmissivity }}$}

10.76 inches (in)

feet $(\mathrm{ft})$

miles (mi)

square miles $\left(\mathrm{mi}^{2}\right)$

cubic feet $\left(f t^{3}\right)$

cubic feet 3 per second $\left(\mathrm{ft}^{3} / \mathrm{s}\right)$

million gallons per day (Mga1/d)

gallons per minute (gal/min)

feet per day (ft/d)

feet squareq per day

$$
\left(f t^{2} / d\right)
$$




\title{
ANALOG MODEL ANALYSIS OF THE NORTH COAST LIMESTONE AQUIFERS, PUERTO RICO
}

\author{
By James E. Heisel, José R. González, and Carlos Cruz
}

\begin{abstract}
Three limestone aquifers on the north coast of Puerto Rico west of Río de la Plata were studied using analog modeling techniques; one contains unconfined water, and two contain water under artesian pressure.
\end{abstract}

Although the total land area studied is about 1,500 square kilometers, the aquifers dip seaward and extend under the ocean for another 3,000 square kilometers. Productive artesian zones have been encountered in a limited area near Barceloneta. Such zones probably exist elsewhere in the study area but no direct data are available for verification.

The water-table aquifer, consisting of the Aymamon and Aguada Limestones plus valley fill and blanket sand deposits, is the major water producer and is better defined by the available data than the two artesian aquifers. The Montebello Limestone Member of the Cibao Formation and the Lares Limestone are the two artesian aquifers. Parts of the Cibao Formation act as confining beds separating the aquifers. Heads as high as 120 meters above sea level were observed when the early artesian wells were drilled; however, due to use of water and possible leakage from the aquifers, heads have declined more than 75 meters in one well in less than 8 years. Flow-meter measurements indicate that some of the artesian wells have ruptured casings through which water is leaking into the water-table aquifer.

An electrical-resistance analog model was used to analyze the ground-water regime in the study area. Questions regarding discharge from the artesian aquifers were resolved by use of the model, indicating, for example, that the hydrology of the area is not affected by a possible east-west trending near-coastal fault once postulated to account for an extensive swampy region. Undersea discharge at the face of the artesian aquifers 30 kilometers offshore is consistent with this analysis, though the discharge probably is less than was formerly supposed. Problems in water-supply feasibility simulated by the model indicate that an additional withdrawal of 0.44 cubic meter per second (10 million gallons per day) is possible from the Cibao Formation, but it will cause a long-term water-level decline equivalent to 50 meters of head in the immediate area.

A steady-state analysis of the amount of water that can be removed from the water-table aquifer in the vicinity of Caño Tiburones over a long period, indicates that 1.6 cubic meters per second ( 37 million gallons per day) can be withdrawn from three well fields without causing seawater intrusion. The model demonstrated also that more water can be withdrawn by additional wells without degrading the chemical quality of widrawn water. 


\section{INTRODUCTION}

The limestone formations of the north coast of Puerto Rico include some of the most important and productive aquifers in the island. The north-coast limestones extend a distance of $125 \mathrm{~km}$ from the municipalities of Aguada to Loíza and can extend inland as much as $22 \mathrm{~km}$ (fig. 1). Throughout much of the area, the aquifers provide the water for industries, municipalities and domestic purposes. Ground-water development has increased dramatically during the last decade. The most intense developments have occurred in the Manati to Arecibo area, where wells are completed in both water-table and artesian aquifers. In the Barceloneta area, (fig. 1) as much as $38,000 \mathrm{~m} / \mathrm{d}$ are pumped from aquifers (Gómez-Gómez and Heisel, 1980). Limestone aquifers near the towns of Dorado, Vega Baja, Vega Alta, and Arecibo, also supply large amounts of water.

The demands for water from the north coast limestone have caused concern among water planners and Commonwealth Government officials. Although the geohydrology of the area is fairly well known, its complexity limits the use of traditional methods for planning and management purposes. Hydrologic models provide the tools essential in the development of alternatives for the optimum development of groundwater resources in the area.
The U.S. Geological Survey, in cooperation with the Puerto Rico Department of Natural Resources and the Puerto Rico Environmental. Quality Board, began a study in 1976 to develop an electrical-analog ground-water flow model of the north-coast limestone aquifers. The study was conducted as part of the cooperative water-resources investigations program between the Geological Survey and agencies within the Commonwealth of Puerto Rico.

\section{Purpose and Scope}

The principal objectives of the study were as follows:

1. To define the hydrologic characteristics of the aquifers within the study area.

2. To define the groundwater budget of the limestone aquifers.

3. To develop, calibrate, and test an electric analog model of the water table and two artesian aquifers in the study area.

4. Using the model, to study regional alternatives of water withdrawal from the aquifers. This includes studies to define effects of current pumpage and to define the long-term optimal yield of the three aquifers. 


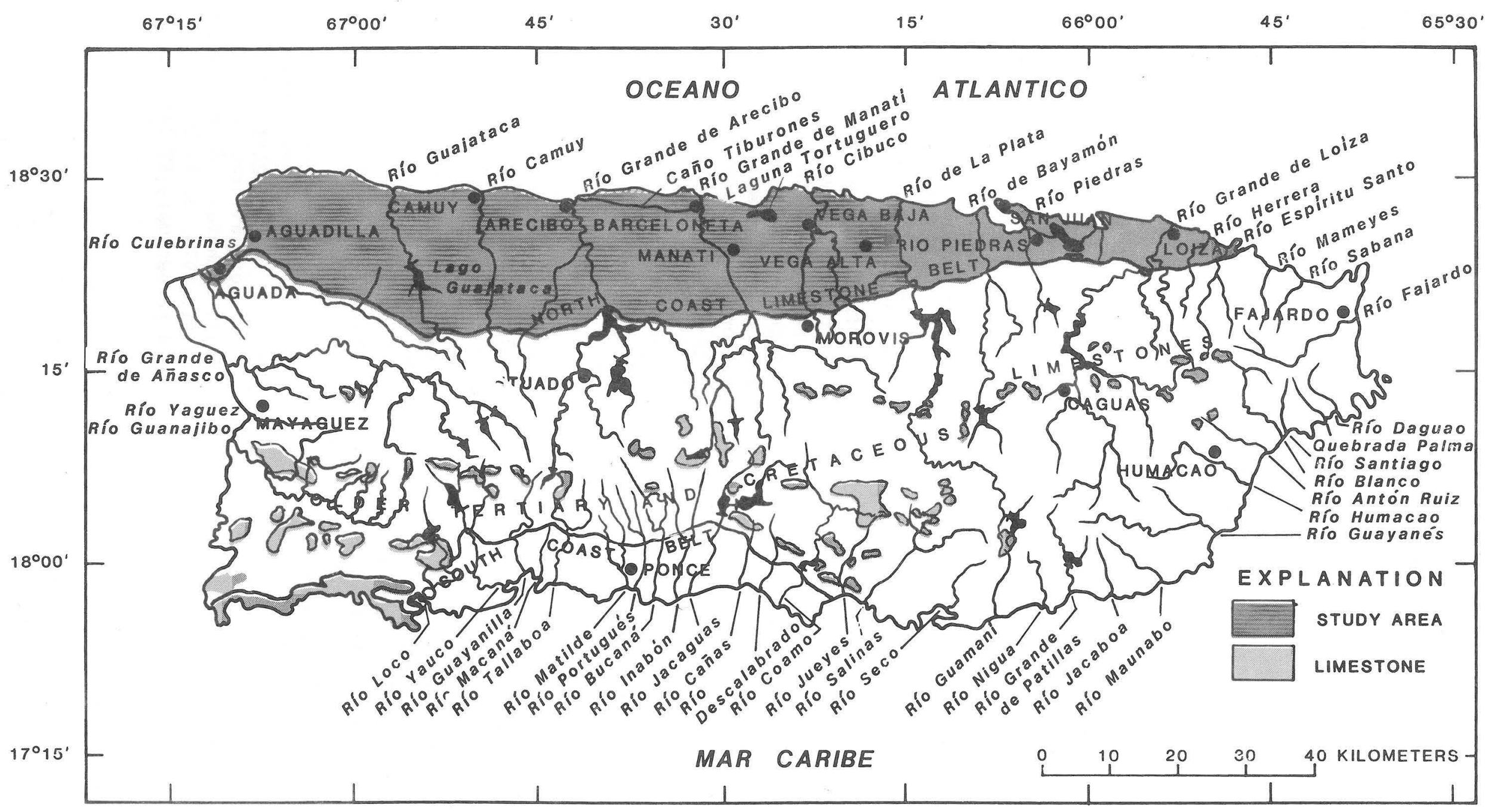

Figure 1.--Area of investigation (modified from Giusti, 1978). 


\section{INTRODUCTION-Continued}

\begin{abstract}
Most of the data used to define the hydrologic properties, water budget, and hydraulic characteristics of the aquifers were obtained from previous studies of the north coast limestone area (Bennett and Giusti, 1972, Giusti and Bennett, 1976, and Giusti, 1978). Field investigations during the study were limited to the collection of water levels in wells and information on well productivity.
\end{abstract}

\section{Acknowledgments}

This study was made possible through the direct assistance of the Department of Natural Resources, which provided an employee to work on the project for two years. Many of the manufacturing firms in the Barceloneta area cooperated fully and provided valuable water-well information. Well drillers provided drillers' logs and informatio.. on we11 construction.

\section{Study Area}

The study area includes the limestones west of Río de la Plata on the north coast of Puerto Rico (fig. 1). The total land area in the study is about $1,540 \mathrm{~km}^{2}$, or about 17 percent of the 1and area of Puerto Rico. About 2,900 $\mathrm{km}^{2}$ of limestone under the ocean were also included in the study. Two artesian aquifers extend under the ocean floor, (Monroe, 1980).
The area east of Río de $1 a$ Plata was not included in the study because the limestone belt is discontinuous and much narrower than the limestone deposits to the west.

\section{Climate}

Puerto Rico is located in the pathway of the nearly constant easterly trade winds. The north coast of the island receives abundant precipitation. Rainfall across the limestone belt ranges from $1,300 \mathrm{~mm} / \mathrm{yr}$ on the coastal plains, to $2,500 \mathrm{~mm} / \mathrm{yr}$ on the southern edge of the limestone. Showers tend to be localized and may occur at any time during the year. In genera1, precipitation follows the general pattern of the rest of the islands; dry season from January to April; many showers in May and June; diminished precipitation through August; and a rainy season from September to December.

Temperatures in the study area average about $24^{\circ} \mathrm{C}$, contributing to a high rate of evapotranspiration (ET) (Giusti, 1978). The brisk, nearly constant winds from the east contribute to ET rates as high as $1140 \mathrm{~mm} / \mathrm{yr}$. The actual ET is probably less than the potential ET. The depth to the water table probably reduces evaporation losses. In the water budget needed for calibration of the model, techniques described by Giusti, 1978, p. 17-22) were used to estimate ET losses. 


\section{GEOLOGY}

The geology of the north coast limestone area has been described in detail by Monroe (1976, 1980), Briggs (1961, 1966), and Briggs and Akers (1965). The following brief description has been adapted from those publications.

The north coast limestones include five formations of Tertiary age. For the purpose of this study, only four of the formations are considered because they contain important aquifers. The oldest unit overlies the San Sebastian Formation, composed of sand, clay, and limestone lenses also of Tertiary age. From oldest to youngest, these formations are:

\section{Lares Limestone}

The Lares Limestone overlies the San Sebastiann Formation or lies directly on the volcanic rocks that forms the core of the island. The formations are composed of relatively pure limestone formed from remains of marine organisms during the middle to late 0ligocene age. It ranges in thickness from 0 to about $500 \mathrm{~m}$. The Lares Limestone is overlain conformably by the Cibao Formation.

\section{Cibao Formation}

The Cibao Formation is composed of white, chalky limestone interbedded with layers of mar1, sand and clay, of 01igocene and Miocene age. It ranges in thickness from 0 to about $310 \mathrm{~m}$. Two principal members, the Montebello Limestone Member and the Quebrada Arenas Limestone Member have been recognized.

\section{Aguada Limestone}

The Aguada Limestone overlies the Cibao Formation, sometimes fingering with the Cibao. The Aguada is almost entirely limestone, with thick to massive beds of calcarenite alternating with beds of clayey limestone. It is fairly uniform, with an average thickness of about 90 $\mathrm{m}$ but as much as about $175 \mathrm{~m}$. The Aguada was deposited during the early Miocene age.

\section{Aymamón Limestone}

The Aymamón Limestone conformably overlies the Aguada Limestone. It is generally uniform, formed by thick beds of almost pure limestone of early Miocene age. Dolomite has replaced some of the limestone in the coastal areas. The Aymamón Limestone ranges in thickness from about 190 to $220 \mathrm{~m}$. 


\section{GEOLOGY-Continued}

Camuy Limestone

The Camuy Formation, formed by younger rocks of Miocene age overlies the Aymamón. It consists of sandy chalk, limestone, and calcareous sandstone, forming discontinuous belts near the coast from Isabela to Dorado. The Camuy Formation does not usually contain water.

Other rocks and unconsolidated deposits of the study area include blanket sands and alluvium. The sands vary in thickness from 0 to $20 \mathrm{~m}$. The alluvium is as thick as $60 \mathrm{~m}$, occurring in the valleys of the major rivers. The alluvium is an important local aquifer in some areas.

The limestone formations extend beyond the north coast and into the ocean (Western Geophysical and Fugro, 1973). The Cibao Formation and Lares Limestone were mapped more than $30 \mathrm{~km}$ north of the coast. The submerged deposits were found to be laterally continuous from Río de la Plata to Río Guajataca, with little or no faulting on the east end. Some partially penetrating north-south trending faults were detected near the mouth of Río Grande de Manatí. Continuous faults were identified west of Río Camuy. The face of the Lares Limestone was found at $4300 \mathrm{~m}$ below sea leve1, while the Camuy Formation was at $2750 \mathrm{~m}$ below sea level.
The structural geology of the limestones is fairly simple, with little faulting or a few faults of small displacement. The dip of the formations is generally 5 degrees or less northward.

A fault extending more than $30 \mathrm{~km}$ from Río Cibuco to Río Grande de Arecibo was postulated by Briggs (1961). His assumption was based on limited evidence including wet areas south of the coast between Arecibo and Dorado. Attempts in 1966 and 1973 to verify the existence of the fault failed. Seismic techniques used by' Western Geophysical and Fugro, Inc. (1973) were not successful. It is now believed that the fault does not exist.

Three significant aquifers have been identified in the North Coast Limestone area. The Aymamón and Aguada Limestones form a water-table aquifer although local artesian conditions are known to exist. The Cibao Formation is separated from the watertable aquifer by clay in the upper part of the Cibao and from the underlying Lares Limestone by an impermeable layer of clay $50 \mathrm{~m}$ or more thick. An artesian zone occurs within the Montebello Limestone Member of the Cibao Formation and within the Lares Limestone. The extent of the artesian zones within both aquifers has not been fully delineated. 


\section{HYDROLOGY}

\section{Ground Water}

In the north coast limestone area, the watertable aquifer is the most important both in size and yield, but the artesian aquifers can also provide a dependable, large volume of water (Gómez-Gómez, and Heise1, 1980).

\section{Water-Table Aquifer}

The water-table aquifer consists mainly of the Aymamón Limestone and Aguada Iimestone. The formations extend laterally across the northern half of the study area (fig. 2), and for some distance offshore.

Locally, unconfined water is in deposits above the limestones. The most significant of the deposits is the alluvium that borders the major rivers in the eastern half of the study area. Other surficial deposits of importance are blanket sands, terrace, swamp, beach, and dune deposits. These latter surficial deposits are not aquifers by themselves, but contribute recharge to the underlying limestones. In most of the area, hydraulic conductivity is low in these deposits retarding water movement through them. Most water is diverted as surface runoff to bordering limestone outcrops. Limestone hills, called mogotes, abound among the surficial deposits. The hills contain large holes around their bases, acting as open channels that accept surface runoff and recharge the underlying limestone (Miotke, 1973).

The two limestone units comprising the water-table aquifer are typical of karst formations and include the following hydraulic characteristics described by LeGrand and others (1976):

(1) a channel or artery network type of permeability, especially near the water table;

(2) rapidly decreasing overall permeability with increasing depth below the water table;

(3) a zone of exceptionally high permeability in valleys;

(4) a very permeable and cavernous unsaturated zone;

(5) salty water in the lower and less permeable part of the aquifer;

(6) moderately low storage of freshwater in long. periods of fair weather.

A11 these features are present in the limestone units of the water-table aquifer. 


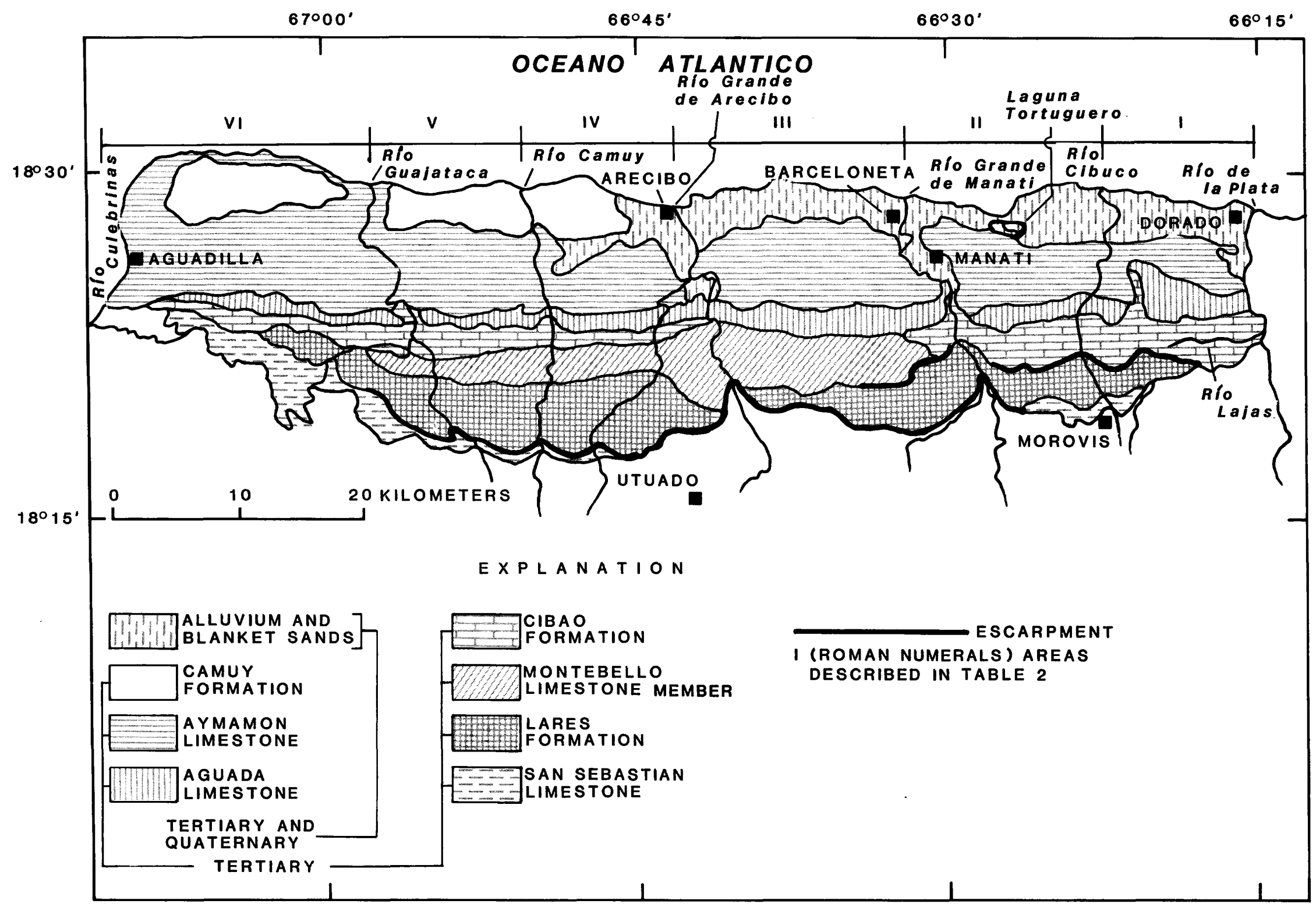

Figure 2.--Outcrops of Limestone in the North Coast Study area, Puerto Rico (adapted by Giusti, 1978, from Briggs and Akers, 1965). 


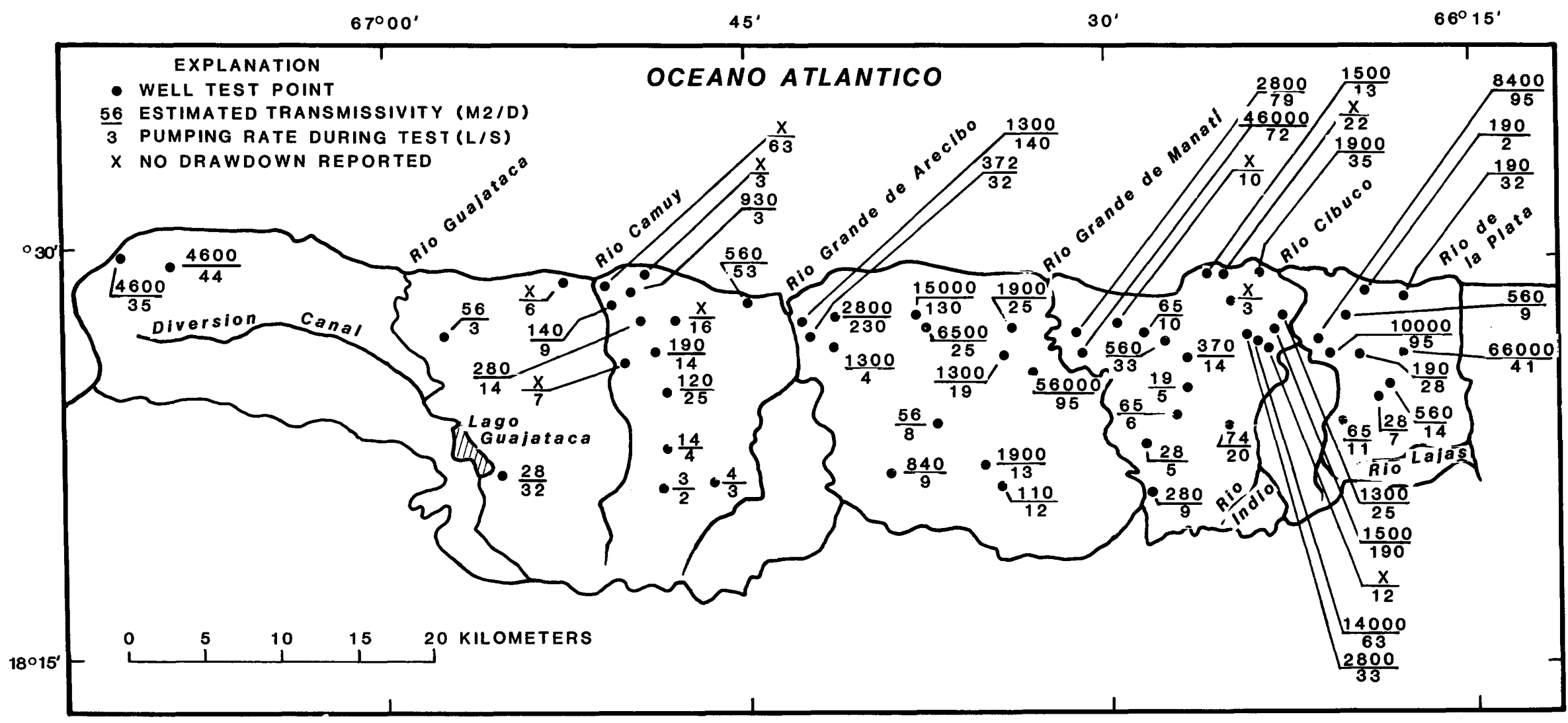

Figure 3.--Pumping rates and estimated transmissivity values at study area tests wells, in the water-table aquifer. 


\section{HYDROLOGY-Continued}

Values of specific

capacity have been determined

by pumping tests conducted in a number of wells in the study area. Specific capacities then were used to estimate transmissivity values employing a method of Theis (1963). The capacity of an aquifer to transmit water is defined by the coefficient of

transmissivity. This is the rate of flow in $\mathrm{m}^{2} /$ day through a vertical section equal to the thickness of the aquifer and unit width under a unit hydraulic gradient. The location and pumping rates of these wells and the estimated transmissivities determined from the aquifer tests are shown in figure 3 .

Transmissivity values estimated from specific capacity tests in the area west of the Río Grande de Arecibo range from 2.3 to 4,600 $\mathrm{m}^{2} / \mathrm{d}$; average transmissivity is $900 \mathrm{~m}^{2} / \mathrm{d}$.

There are three times as many wells with tests east of the Río Grande de Arecibo than to the west. The transmissivities east of Arecibo range from 19 to $66,000 \mathrm{~m}^{2} / \mathrm{d}$ and the average is over 7,000 $\mathrm{m}^{2} / \mathrm{d}$.

The limestones become thinner to the east of the Rio Grande de Manati and the Lares Limestone pinches out. Despite the thinning of the limestones, one of the largest specific capacities on record for the limestone was observed during a pumping test south of Vega Alta. Estimated transmissivity for this test is 15,000 $\mathrm{m}^{2} / \mathrm{d}$.
Artesian Aquifers

Artesian pressures were first noted in 1968 during the drilling of a deep well in the Cruce Dávila area of Barceloneta (Giusti, 1968). One artesian zone was found in the Montebe11o Limestone Member of the Cibao Formation at a depth of about $350 \mathrm{~m}$ and a second zone was encountered at about $500 \mathrm{~m}$ in the Lares Limestone. Subsequently, more deep wells were drilled to tap the artesian aquifers. At the completion of the study (1979), there were 15 deep artesian wells in the Barceloneta-Manatí Cruice Dávila area (table 1 and fig. 4), three of which (1,9 and 10) are open to both the Montebello Limestone Member and Lares Limestone. A11 of these wells flowed when first drilled. This area, from 5.5 $\mathrm{km}$ west to $6 \mathrm{~km}$ east of the Río Grande de Manatí is the only place where artesian aquifers capable of substantial development have been discovered. The three wells $(12,13$, and 14) near the ocean northeast of Manatí are flowing wells. Well 12 is open to both artesian aquifers; wells 13 and 14 produce only from the Lares. The well east of Manati (15), open only to Lares, flowed at a lower rate than the others. The well no longer flows.

Heads have declined in both artesian aquifers. Artesian head is measured at the wells and for comparison, with each other, are adjusted to mean sea level. Adjusted water levels in well 10 south of Cruce Dávila are shown in 


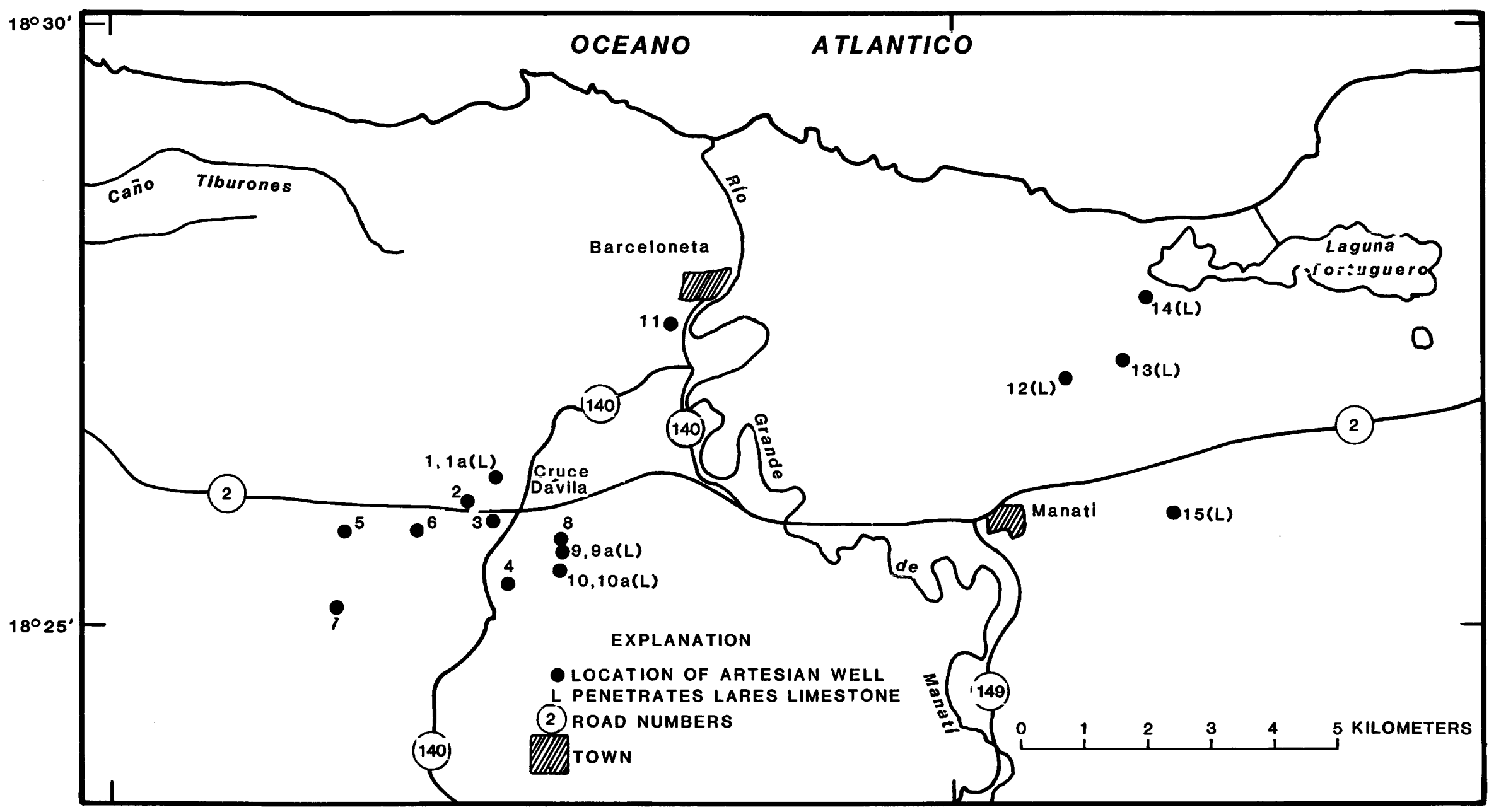

Figure 4.--Location of artesian wells in the Cruce Dávila area. 


\section{HYDROLOGY-Continued}

Table 1.--Estimated transmissivities of artesian wells in the Cruce Dávila area.

\begin{tabular}{|c|c|c|c|c|c|}
\hline $\begin{array}{c}\text { WELL } \\
\text { NUMBER } \\
\text { (Refer tofig. 4) }\end{array}$ & $\begin{array}{l}\text { PRESSURE } \\
\text { HEAD, } \\
\text { METERS } \\
\text { ABOVE } \\
\text { SEA LEVEL }\end{array}$ & $\begin{array}{l}\text { DISCHARGE (Q) } \\
\text { CUBIC METERS } \\
\text { PER SECOND }\end{array}$ & $\begin{array}{l}\text { DRAWDOWN } \\
\text { (S), } \\
\text { METERS }\end{array}$ & $\begin{array}{l}\text { SPECIFIC } \\
\text { CAPACITY } \\
M^{2} / S\end{array}$ & $\begin{array}{c}\text { ESTIMATED } \\
\text { TRANSMISSIVITY } \\
M^{2} / D\end{array}$ \\
\hline $\begin{array}{l}1 \\
\operatorname{la}(\mathrm{L}) \\
2 \\
3 \\
4 \\
5 \\
6 \\
7 \\
8 \\
9 \\
9 a(\mathrm{I}) \\
10 \\
10 a(\mathrm{I}) \\
11 \\
12(\mathrm{~L}) \\
13(\mathrm{~L}) \\
14(\mathrm{~L}) \\
15(\mathrm{~L})\end{array}$ & $\begin{array}{l}139 \\
130 \\
141 \\
147 \\
159 \\
146 \\
151 \\
133 \\
131 \\
138 \\
138 \\
123^{*} \\
131^{*} \\
111 \\
127 \\
128 \\
132 \\
\text { NA }\end{array}$ & $\begin{array}{c}0.022 \\
.009 \\
\mathrm{NA} \\
.063 \\
.16 \\
.16 \\
.05 \\
.047 \\
.11 \\
.16 \\
.13 \\
\mathrm{NA} \\
\mathrm{NA} \\
.013 \\
.065 \\
.028 \\
.025 \\
.0006\end{array}$ & $\begin{array}{r}13 \\
56 \\
53 \\
63 \\
68 \\
40 \\
56 \\
2 \\
68 \\
69 \\
69 \\
\text { NA } \\
\text { NA } \\
110 \\
100 \\
104 \\
123 \\
\text { NA }\end{array}$ & $\begin{array}{c}0.0016 \\
.0002 \\
\mathrm{NA} \\
.001 \\
.002 \\
.004 \\
.001 \\
.024 \\
.00 ? \\
.002 \\
.002 \\
\mathrm{NA} \\
\mathrm{NA} \\
.0001 \\
.0006 \\
.0003 \\
.0002 \\
\mathrm{NA}\end{array}$ & $\begin{array}{r}220 \\
27 \\
\text { NA } \\
124 \\
310 \\
420 \\
110 \\
3,110 \\
220 \\
310 \\
310 \\
\text { NA } \\
\text { NA } \\
16 \\
83 \\
36 \\
27 \\
\text { NA }\end{array}$ \\
\hline \multicolumn{6}{|c|}{$\begin{array}{l}\text { * Not based on original pressure. } \\
\text { NA Data not available. } \\
\text { L Finished in Lares Limestone, all others in Montebello Iimestone } \\
\quad \text { Member of the Cibao Formation. }\end{array}$} \\
\hline & & & & t drilled. & \\
\hline
\end{tabular}

figure 5 to illustrate the water-level drop from March 1974 to July 1977 in the Montebello. It is possible that part of the continuing decline is owing to pressure loss from water flowing from the Montebello into the water-table aquifer through damaged casings of abandoned wells. Well 10 was not being used as a supply well during the period represented by the data. During this period withdrawals from the Montebe1lo averaged about $0.2 \mathrm{~m}^{3} / \mathrm{s}$. Present (1977) withdrawa1s are at a rate of about $0.15 \mathrm{~m} / \mathrm{s}$.

Water levels in the Lares aquifer were monitored from
1974 through 1977 in we11 14 north of Manatí. The pattern of water-level decline (fig.5) was similar to that in the Montebello. The Lares Limestone is not used for supply as much as the Montebello; withdrawals average about 0.04 $\mathrm{m}^{3} / \mathrm{s}$.

Transmissivities ( $T$ ) in the artesian aquifers (table 1 ) were estimated using the method described by Brown (1963), in which $\mathrm{T}$ is largely a function of the specific capacity determined from a pumping test. Some of the hydrologic parameters that influence artesian conditions in the system are summarized in table 2 . 
Table 2.--General characteristics of artesian aquifer outcropping across the north coast limestone bolt.

\begin{tabular}{|c|c|c|c|c|c|c|c|}
\hline $\begin{array}{c}\text { AREA } \\
\text { (Roter to flo. 2) }\end{array}$ & FORMA & TION & THICKNES 8 & $\begin{array}{l}\text { HYORAULIC } \\
\text { CHARAC- } \\
\text { TERIBTICS }\end{array}$ & $\begin{array}{c}\text { CONFINING } \\
\text { BED }\end{array}$ & $\begin{array}{c}\text { RECHARGE } \\
\text { AREA }\end{array}$ & $\begin{array}{c}\text { DI8CHARGE } \\
\text { AREA }\end{array}$ \\
\hline I & $\begin{array}{l}\mathrm{L} \\
\mathrm{C}\end{array}$ & & $\begin{array}{r}\mathrm{NF} \\
\mathrm{F}\end{array}$ & $-\bar{G}$ & Yes & $\begin{array}{l}\text { Sma } 11 \\
\text { SD }\end{array}$ & $\begin{array}{l}\text { os } \\
\text { os }\end{array}$ \\
\hline II & $\begin{array}{l}\mathrm{L} \\
\mathrm{C}\end{array}$ & & $\begin{array}{l}\mathrm{F} \\
\mathrm{F}\end{array}$ & $\overline{N G}$ & $\overline{\mathrm{NE}}$ & $\mid \begin{array}{c}(1 / 2) G-(1 / 2) S D \\
S D\end{array}$ & $\begin{array}{l}\text { OS } \\
\text { OS }\end{array}$ \\
\hline III & $\begin{array}{l}\mathrm{L} \\
\mathrm{C}\end{array}$ & & $\begin{array}{l}\mathrm{F} \\
\mathrm{F}\end{array}$ & $\begin{array}{l}G \\
G\end{array}$ & $\overline{\mathrm{NA}}$ & G & $\begin{array}{l}\text { OS } \\
\text { os }\end{array}$ \\
\hline IV & $\begin{array}{l}\mathrm{I} \\
\mathrm{C}\end{array}$ & & $\begin{array}{l}\mathrm{F} \\
\mathrm{F}\end{array}$ & $\begin{array}{l}G \\
G\end{array}$ & $\begin{array}{r}P \\
\text { Yes }\end{array}$ & $\begin{array}{c}\mathrm{G} \\
3 / 4 \mathrm{G}-1 / 4 \mathrm{SD}\end{array}$ & $\begin{array}{l}\text { os } \\
\text { os }\end{array}$ \\
\hline $\mathrm{V}$ & $\begin{array}{l}\mathrm{L} \\
\mathrm{C}\end{array}$ & & $\begin{array}{l}\mathrm{F} \\
\mathrm{F}\end{array}$ & $\begin{array}{l}\mathrm{G} \\
\mathrm{G}\end{array}$ & $\begin{array}{l}\text { Yes } \\
\text { Yes }\end{array}$ & G & $\begin{array}{l}\text { os } \\
\text { os }\end{array}$ \\
\hline VI & $\begin{array}{l}\mathrm{L} \\
\mathrm{C}\end{array}$ & & $\begin{array}{r}\mathrm{NF} \\
\mathrm{F}\end{array}$ & $\overline{\mathrm{NG}}$ & $\overline{\mathrm{NE}}$ & $\begin{array}{r}S D \\
S D-S S\end{array}$ & NS \\
\hline \multicolumn{2}{|c|}{ Symbols: } & \multicolumn{3}{|c|}{$\begin{array}{l}F=\text { Favorable } \\
N F=\text { Not Favorable } \\
L=\text { Lares Limestone } \\
C=\text { Cibao Limestone } \\
G=\text { Good } \\
\text { NG }=\text { No Good } \\
\text { NS }=\text { Near Shore }\end{array}$} & \multicolumn{2}{|c|}{$\begin{aligned} \mathrm{NA} & =\text { Not Apparent } \\
-- & =\text { Unknown } \\
\mathrm{SD} & =\text { Surface Drainage } \\
\mathrm{SS} & =\text { Steep Slopes } \\
\mathrm{P} & =\text { Probable } \\
\mathrm{NE} & =\text { Nonexistent } \\
\mathrm{OS} & =\text { Off Shore }\end{aligned}$} & \\
\hline
\end{tabular}

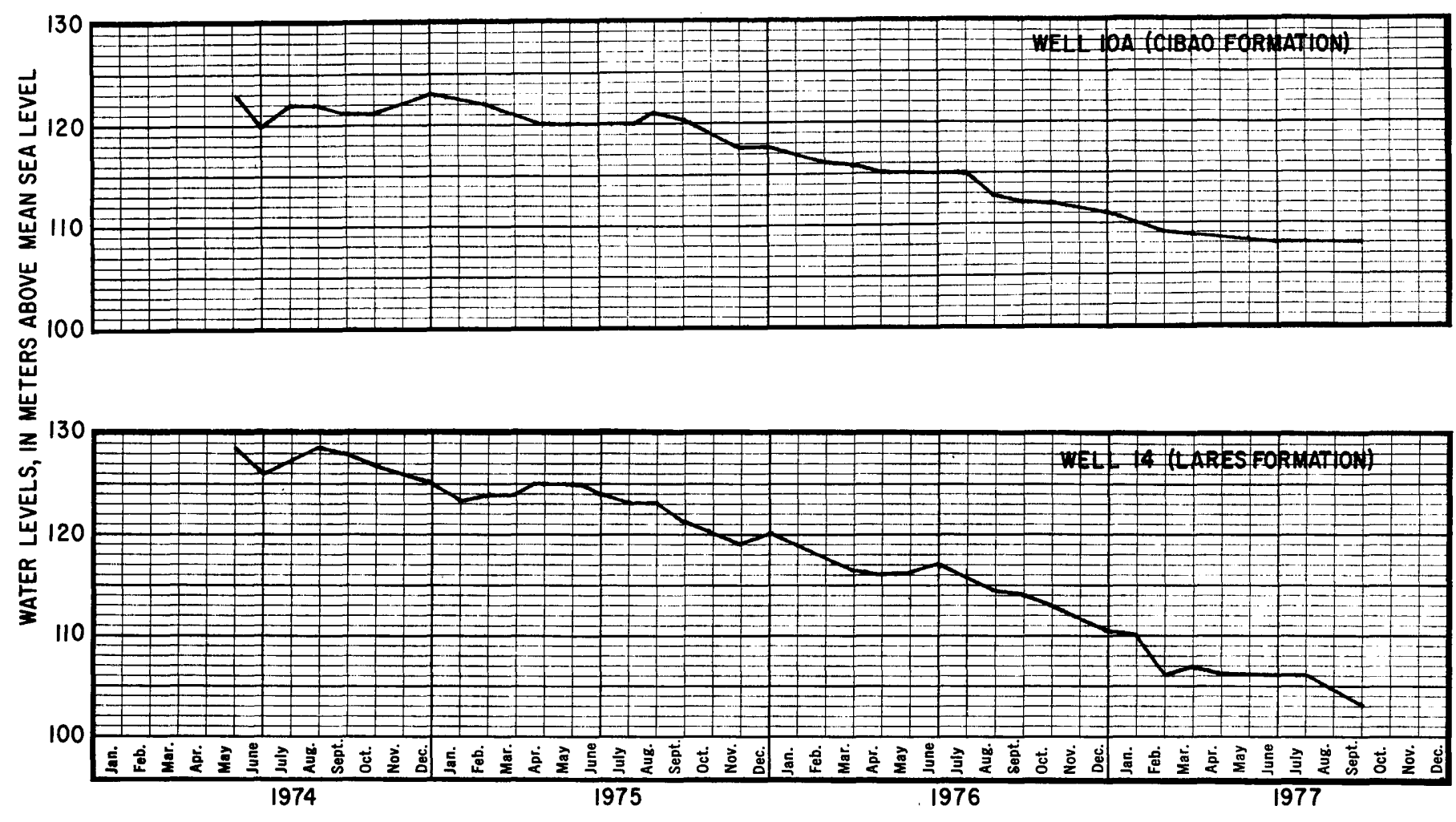

Figure 5.--Water-level declines in artesian aquifers, Cruce Dávila area, Puerto Rico. Adjustment to mean sea level datum by adding wellhead elevation to hydrostatic pressure. 


\section{HYDROLOGY-Continued}

Ground Water-Surface Water Relationships

The outcrop areas of the limestone formations and the six segments (Roman numerals) into which the region has been divided for discussion purposes are as follows (See fig. 2.):

Area I: between Río de la Plata and Río Cibuco

Area II: between Río Cibuco and Río Grande de Manatí

Area III: between Río Grande de Manatí and Río Grande de Arecibo

Area IV: between Río Grande de Arecibo and Río Camuy

Area V: between Río Camuy and Río Guajataca

Area VI: between Río Guajataca and the west coast

Precipitation on the outcrops of the limestones of the study area may infiltrate into the limestone or flow away overland, depending on the surface material or topography. In areas of high permeability or typical karst topography, most of the precipitation, after ET losses, recharges the aquifers. Recharged water moves through the aquifer to discharge areas. Discharges occur as baseflow to rivers, into swamps, lowlands, and coastal lagoons. Discharges also. occur directly into the ocean.
Ground-water discharges west of Río Grande de Arecibo are mostly into the three principal rivers: Río Guajataca, Río Camuy, and Río Tanamá. Giusti (1978), measured the flow of these rivers upstream from the southern edge of the limestone formation, and also near the coast. He estimated aquifer discharges as the base-flow differences between the upstream-downstream measurements. The estimates were as follows:

Río Guajataca - $0.5 \mathrm{~m}_{2}^{3} / \mathrm{s}$

Río Camuy - $1.2 \mathrm{~m} / \mathrm{s}$

Río Tanamá - $1.0 \mathrm{~m}^{3} / \mathrm{s}$

Río Grande de

Arecibo - $2.2 \mathrm{~m}^{3} / \mathrm{s}$

Giusti $i_{3}$ also assumed that about $1.2 \mathrm{~m}^{3} / \mathrm{s}$ of the baseflow from Río Grande de Arecibo comes from drainage areas east of its channel. The net ground-water discharge west of Río Grande de Arécibo thus approximates $3.7 \mathrm{~m}^{3} / \mathrm{s}$.

Ground-water withdrawals west of Río Grande de Arecibo are relatively small because the depth of the water table and abundance of surface-water supplies. An unknown amount of ground-water discharges directly to the ocean through the seabed.

The most significant hydrologic feature between Río Grande de Arecibo and Río Grande de Manatí, is the Caño Tiburones (fig. 1). The Caño, a reclaimed swamp along the Atlantic coast, extends almost the entire $16.4 \mathrm{~km}$ between the 


\section{HYDROLOGY-Continued}

two rivers, varying in width from 1.5 to $3 \mathrm{~km}$. Much of the land surface of the Caño is below mean sea level. Drainage canals and a pumping station were built to drain water from the area. Tida1 gates placed near the eastern end of the area keep most of the seawater out.

Pumping records and flow measurements show that about 5 $\mathrm{m} / \mathrm{s}$ are discharged from the Caño into the sea (Díaz, 1973). Chemical analyses show that the water is about 30 percent seawater, entering the area through solution channels in the limestone. The freshwater being pumped to the ocean (about $3.5 \mathrm{~m}^{3} / \mathrm{s}$ ) flows into the Caño from the limestone hills to the south.

The principal surfacehydrologic feature between Río Grande de Manatí and Río Cibuco is Laguna Tortuguero. The lagoon receives a large part of the surface runoff from the intervening drainage area between the two rivers, and discharges directly to the sea. Chloride concentrations in the lagoon range from 320 to $980 \mathrm{mg} / \mathrm{L}$, indicating only minor seawater intrusion (Quiñones, 1976). Laguna Tortuguero also receives ground water upwelling from the blanket sands and muck, as from ditches that drain nearby areas.

Other swampy areas between Río Cibuco and Río Grande de Manatí drain directly to the ocean. About 50 percent of the drainage area between the two rivers drains to Laguna Tortuguero, with the remaining draining to the ocean and the lower stream reaches. Bennett and Giusti (1972) estimated about 1.6 $\mathrm{m} / \mathrm{s}$ discharge to the ocean from the area.

Inland in the Rio Cibuco - Río Grande de Manatí section where the Cibao Formation crops out, ephemeral systems flow northward into sinkholes in the Aguada Limestone. These streams recharge the water-table aquifers of the Aguada and Aymamón Limestones. Recharge into the Cibao Formation is limited because the clayey nature of the formation in this area.

The easternmost section of the study area between Río Cibuco and Río de la Plata is similar to the areas east of Río Grande de Arecibo. Ground-water discharges to the ocean occur through low-swampy coastal areas. Giusti (1978), eştimated that about 0.41 $\mathrm{m}^{3} / \mathrm{s}$ of ground-water discharges to the ocean through drainage canals.

Regionalization of Aquifer Characteristics for Modeling

Modeling of an aquifer system requires knowledge and use of hydraulic and hydrogeologic properties, such as water levels, recharge and discharge, transmissivity, and storage coefficient values. 


\section{HYDROLOGY-Continued}

\section{Transmissivity}

Transmissivity values for the limestone aquifers in the study area were obtained from data collected by Giusti (1978). Values for the watertable aquifers (Aguada and Aymamón) are summarized in figure 3. Transmissivity values for the artesian component of the Cibao Formation were estimated from tests in the Cruce Dávila area. Values for the artesian part of the Lares Limestone were similarly obtained from tests near Manati. Transmissivity is analogous to the reciprocal of electric resistance; therefore it is possible to apply electrical storage and flow principles to the study of water in aquifers (Freeze and Cherry, 1979, p. 360).

For the purposes of the model, transmissivities were regionalized and extrapolated to cover the study area (figures 6 thru 8). Regionalized values are not as variable as those based on individual tests, partly because of the nature of the aquifer and of the grid interval used in the model. Individual tests are affected by cavernous conditions or solution channels giving an erroneously high transmissivity value. These exceptionally high values are averaged with much lower values or disregarded entirely, to ensure that the entire aquifer will be accurately modeled on a regional basis. An average between the most and least favorable conditions was used.
Water Levels

Ground water levels in the water table aquifers of the north coast limestone (Aymamón and Aguada) were obtained from data collected by Giusti (1978). The static water levels were supplemented by data collected during this study and modified as shown in figure 9.

In the artesian aquifers (Montebello Limestone Member of the Formation, Cibao and Lares Limestone), the analyses were based on pressures reported in driller's logs and records and in other records. Artesian pressures have been reduced as water is withdrawn from the aquifers. The heads in the artesian aquifers were not contoured because of the scarcity of wells.

\section{Recharge and Storage Coefficients}

Ground-water recharge in the study area was computed as the change in storage plus baseflow. The net change in storage (S) was computed from water-budget data collected by Giusti and Bennett (1976, table 2). Data for 12 geographical regions (about two thirds of the area in this study) are summarized in table 3 . The data include only the basins for which streamflows have been measured. The recharge to the remaining one third of the study area was estimated on the basis of other climatological and hydrologic records. 


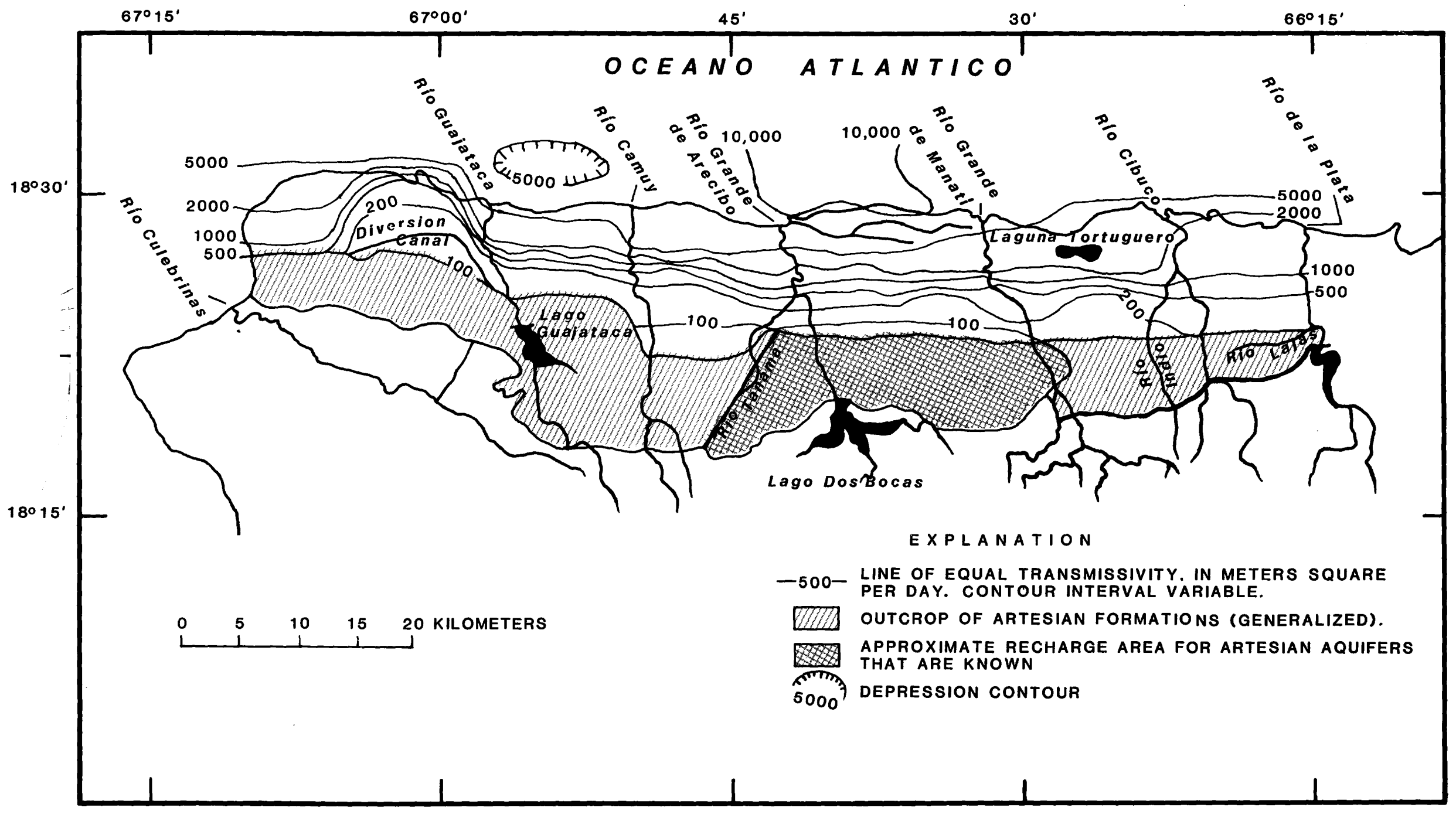

Figure 6.--Estimated transmissivity variation in the water-table aquifer. 


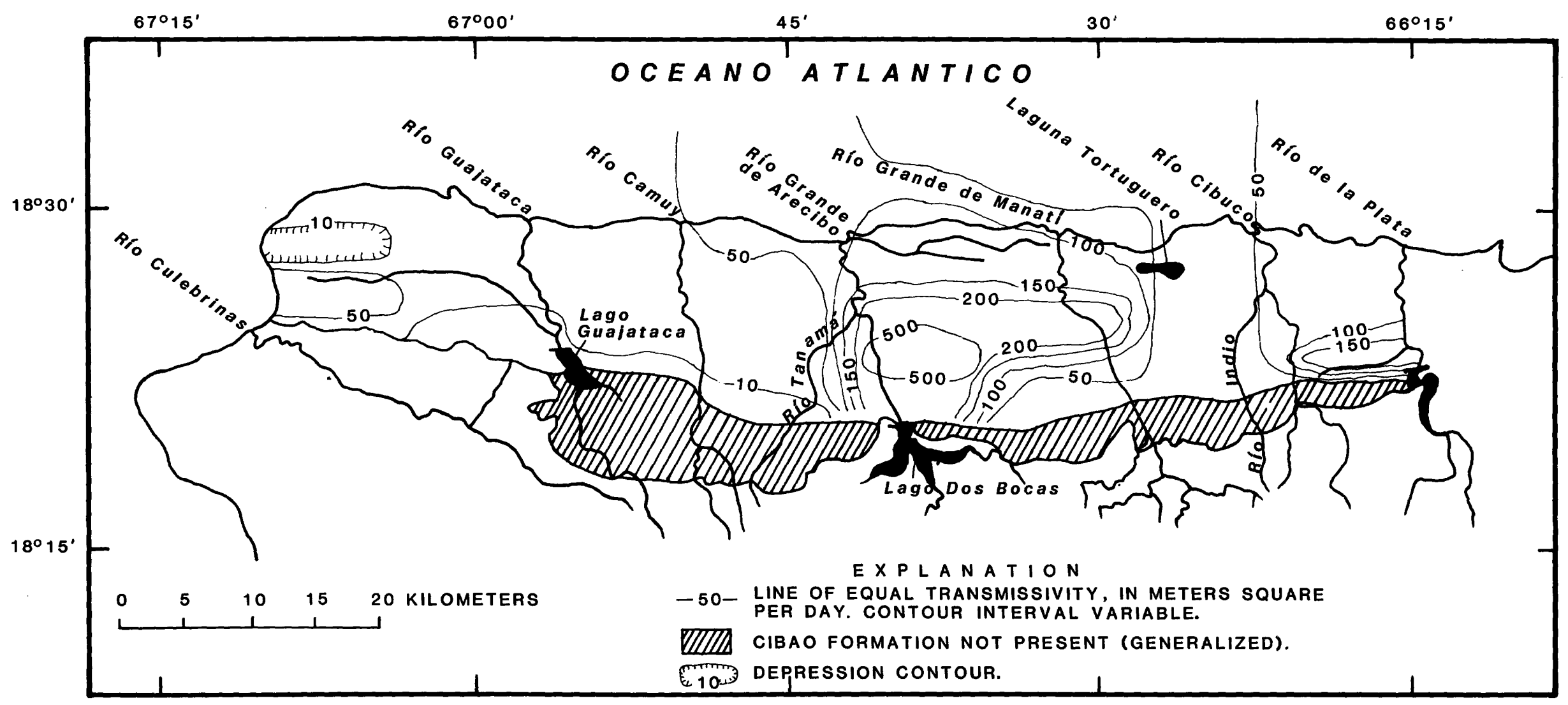

Figure 7.--Transmissivity as modeled in the Cibao Formation. 


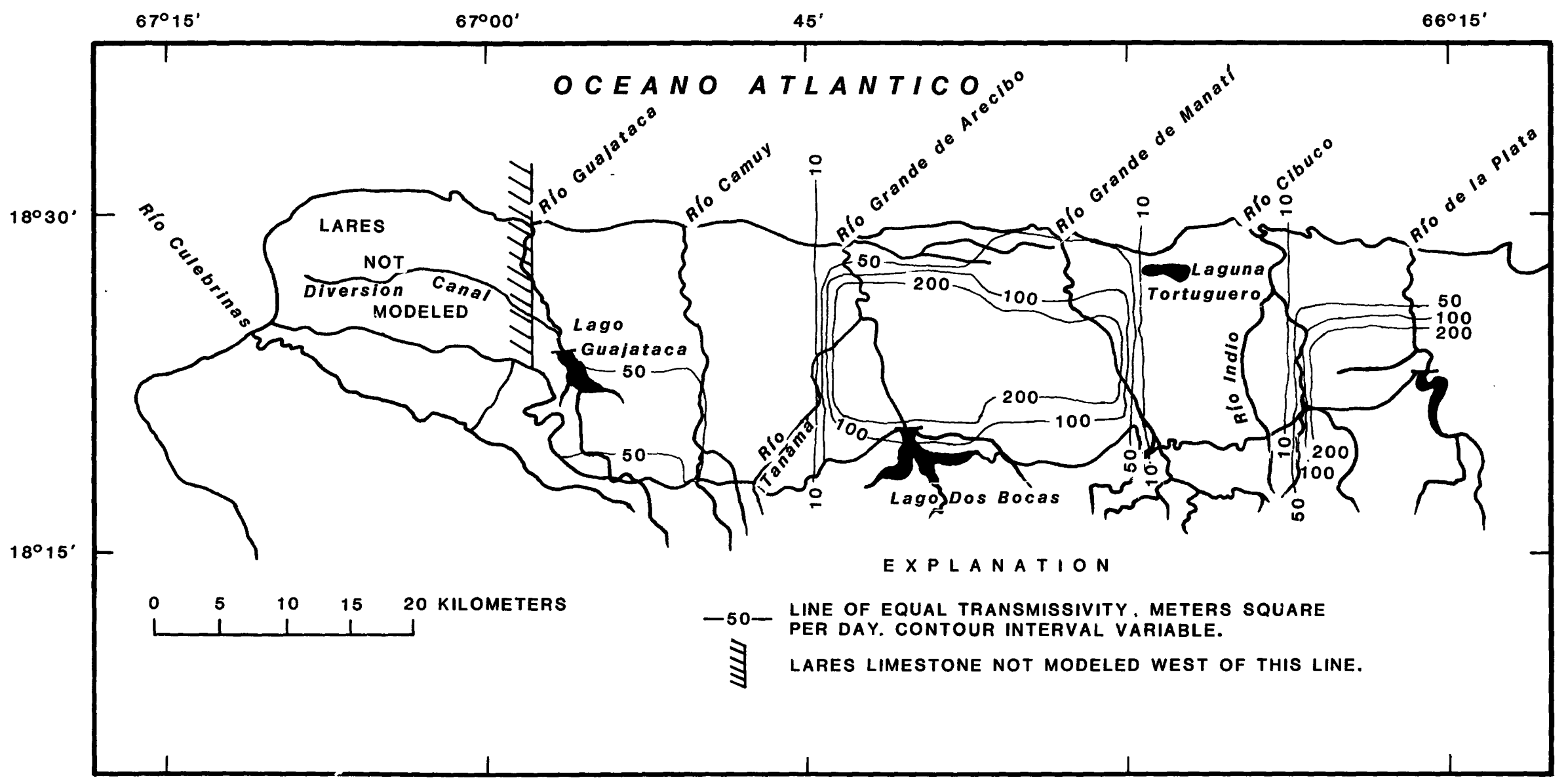

Figure 8.--Transmissivity as modeled in the Lares Limestone. 


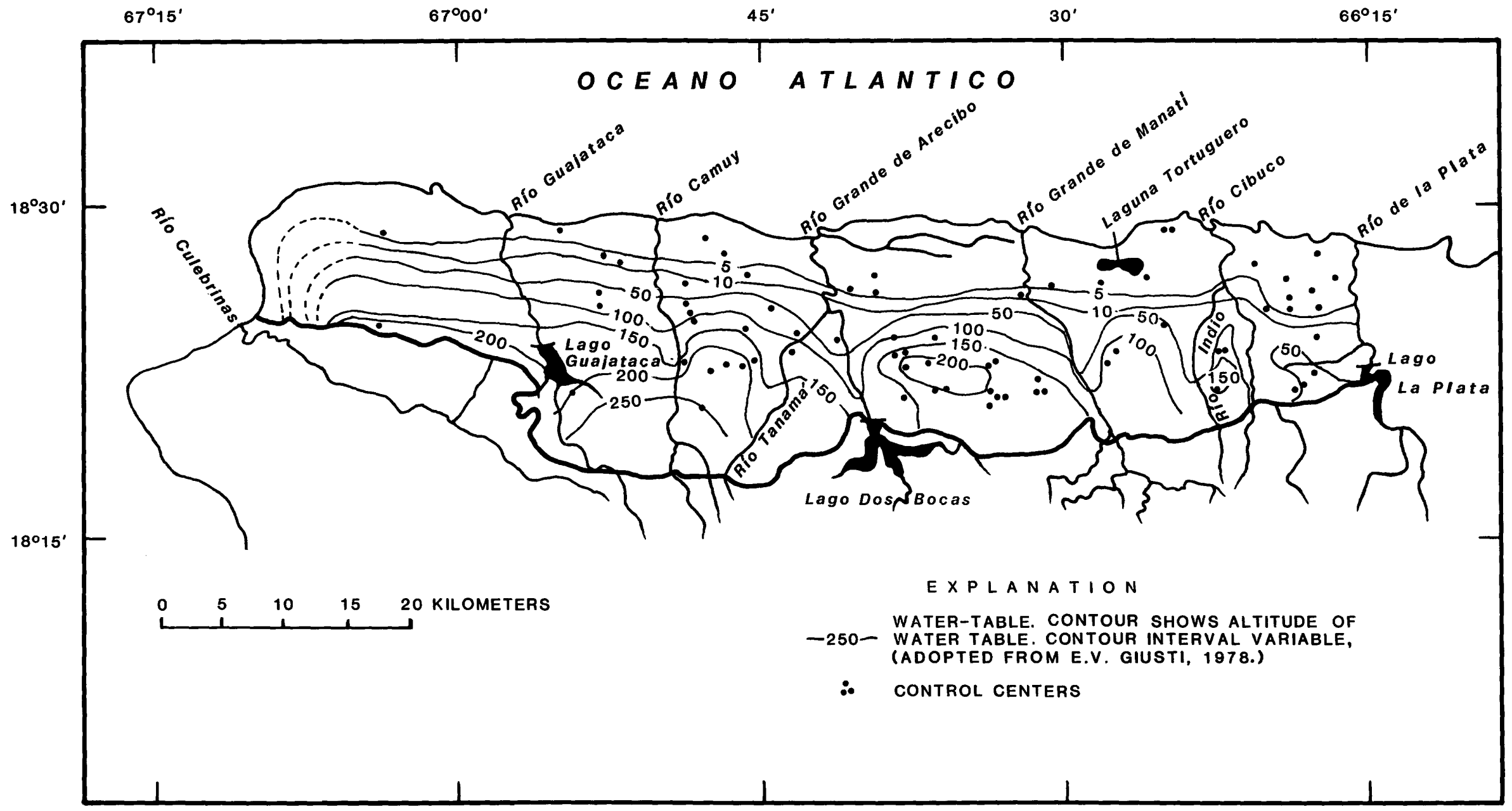

Figure 9.--Water-table altitudes in the North Coast Limestone belt (adapted from Giusti, 1978). 


\section{HYDROLOGY-Continued}

The baseflow was considered as rejected recharge. The flow of the major rivers was measured by Giusti and Bennett, (1976) upstream from the limestone formations as well as near the river mouths in the coastal areas (fig. 10). Hydrograph separation techniques were used to separate the baseflow and excess runoff.

The major known recharge areas to the artesian aquifers are the closed, blanket-sand filled basins in the vicinity of the town of Florida. Because the aquifers are essentially full, water which infiltrates the blanket sands moves laterally to the rivers or over the top of the clayey Cibao Formation to the watertable aquifers. Where relatively impermeable surface materials inhibit infiltration, drainage patterns form and runoff increases. Recharge to the aquifer is minimum. The northward dip of the formations enhances the development of north-flowing drainage cuts across successjively younger formations.

Surface drainage has formed on the Cibao Formation in areas $I$, IT, IV and VI (fig. 2 and table 2) and on the Lares Limestone in areas II, and VI. In area $I$, the Cibao outcrop is drained by Rio Lajas (fig. 2) which has a high baseflow, an indication that recharge to the formation is minimal. Since the Montebello Limestone Member is absent, the likelihood of finding large artesian supplies to the north of the outcrop is slim. In area II the drainage pattern consists of tributaries to the Río Cibuco and small stream, which

Table 3.--Recharge values for subareas of the north coast limestone belt, in millimeters for the period November 1969 to October 1970.

\begin{tabular}{|c|c|c|c|c|}
\hline $\begin{array}{c}\text { AREA NUMBER } \\
\text { (fig. 10) }\end{array}$ & AREA NAME & $\Delta s^{1 \prime}$ & BASE FLOW $\underline{2}$ & RECHARGE \\
\hline $\begin{array}{l}1 \\
2 \\
3 \\
4 \\
5 \\
6 \\
\\
7 \\
8 \\
9 \\
10 \\
11 \\
12\end{array}$ & $\begin{array}{l}\text { Northwest } \\
\text { Upper Guajataca } \\
\text { Lower Guajataca } \\
\text { Río Camuy } \\
\text { Río Tanamá } \\
\text { Río Grande de } \\
\text { Arecibo } \\
\text { S. Tiburones } \\
\text { N. Tiburones* } \\
\text { Río Grande de } \\
\text { Manatí } \\
\text { Tortuguero } \\
\text { Cibuco } \\
\text { Río Lajas }\end{array}$ & $\begin{array}{r}530 \\
230 \\
250 \\
20 \\
280 \\
\\
640 \\
230 \\
-1,830 \\
-200 \\
50 \\
-15 \\
-230\end{array}$ & $\begin{array}{c}I \\
I \\
210 \\
240 \\
330 \\
\\
I \\
I \\
-1,620 \\
\\
340 \\
52.0 \\
180 \\
260\end{array}$ & $\begin{array}{r}530 \\
230 \\
460 \\
260 \\
610 \\
\\
640 \\
230 \\
-210 \\
\\
140 \\
570 \\
165 \\
30\end{array}$ \\
\hline
\end{tabular}

* Freshwater discharge from Caño Tiburones. Giusti and Bennett, 1976, p. 28.

Giustj. and Bennett, 1976, p. 32.

I Insignificantly low value. 


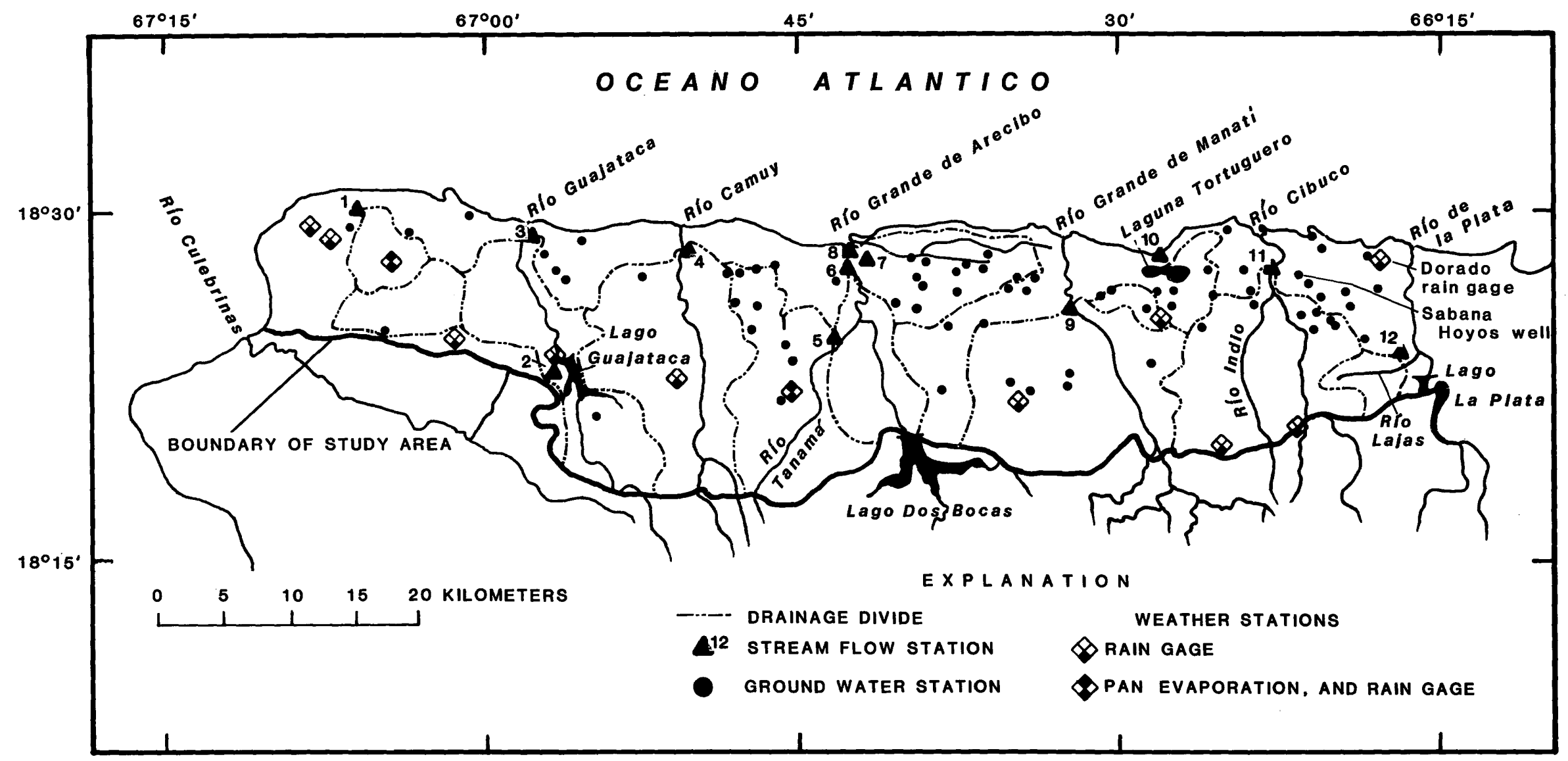

Figure 10.--Location of streamflow stations and other data-collection points (After Giusti and Bennett, 1976). 


\section{HYDROLOGY-Continued}

rise in the Lares Limestone or Cibao Formations and end in sinkholes in the Aguada Limestone. There is little opportunity for water to enter the Lares or Cibao and therefore artesian supplies in these formations north of this area are not expected.

In area III, conditions are more favorable for development of artesian conditions. Karst landforms in the Montebello Limestone Member provide ready infiltration, and the marl in that part of the Cibao Formation overlying Montebe1lo forms a confining bed so that water does not escape into the younger formations. The Lares Limestone outcrop area also has karst landforms north of which artesian wells have been located.

Some surface streams rise in the Cibao Formation in area IV but they also enter sinkholes in the same formation after two or three $\mathrm{km}$ and probably discharge to the watertable aquifer or to the principal streams. There are karst landforms in the Lares Limestone indicating favorable conditions for recharge. The Río Tanamá, the sizable western tributary of Río Grande de Arecibo, is very deeply entrenched in both the Cibao and Lares and has a large baseflow, indicating that much of the water entering these formations quickly flows to the river.

In area $\mathrm{V}$ there are many very short streams that flow north across the Cibao but seem to disappear near the contact with the Aguada Limestone and enter that formation. The Rio Camuy, like the Río Tanama to the east, is deeply incised in the Cibao Formation and Lares Limestone, thus draining much of the recharge those formations receive.

Both Lares and Cibao outcrops in area VI west of the Rio Guajataca have welldeveloped drainage and runoff flows south into the Rio Culebrinas at the southern. boundary of the limestone belt and discharges westward to the ocean. Any recharge to these formations probably discharges quickly to the Río Culebrinas because of the drainage pattern and two south-facing scarps, one of which marks the southern limit. of the limestone belt; the other scarp is in the upper part of the Cibao Formation.

Some areas have not been included in the water-budget analysis. Most of these are coastal areas lying between the gaged basins and downstream from the lowest stream gages. One such area is the eastern end of the study area north of the Río Lajas and east of the Río Cibuco. Part of this area drains to the Rio de la Plata, some has no surface drainage, and the northern part is a swampy, ground-water discharge area along the coast, drained in places by canals. 


\section{HYDROLOGY-Continued}

Data from the $27 \mathrm{~m}$ in depth Sabana Hoyos recordingobservation well (fig. 10) in depth, were used to evaluate the recharge in the area between the Rios Cibuco and de 1a Plata. Daily water levels were scanned to identify periods of rising water levels, that is, periods of active recharge.

The descending limb of the hydrograph trace was then extended graphically in a smooth curve for the period of the rise, as illustrated in figure 11. Recharge for a day was considered to be the excess of the recorded water level over that of the extended falling limb subtracting out the previous day's recharge. During periods of successive daily decline no recharge was considered to have occurred. Water-level rise during the recharge periods was then accumulated on a monthly basis for all. available record and averages of the monthly values were calculated. This average month1y recharge, as manifest by the rise of water levels in the aquifer, was quantified areally by applying a specific yield or storage coefficient of 10 percent. Resultant values are listed in table 4. The annual variation is illustrated in figure 12 where, for comparison, are shown the average monthly values of precipitation for a weather station at Dorado, (National Weather Service data) about $5 \mathrm{~km}$ northeast of the well site (fig. 10).

Table 4.--Average-monthly recharge, Sabana Hoyos well.

\begin{tabular}{l|c|c}
\hline MONTH & $\begin{array}{c}\text { MONTHS OF } \\
\text { RECORD ANALYZED }\end{array}$ & RECHARGE, MILLIMETERS \\
\hline January & 11 & 15 \\
February & 13 & 6 \\
March & 10 & 14 \\
Apri1 & 12 & 18 \\
May & 14 & 14 \\
June & 9 & 9 \\
July & 12 & 10 \\
August & 12 & 13 \\
September & 10 & 12 \\
October & 14 & 22 \\
November & 13 & 30 \\
December & 14 & 32 \\
& Total 144 & Yearly \\
\end{tabular}




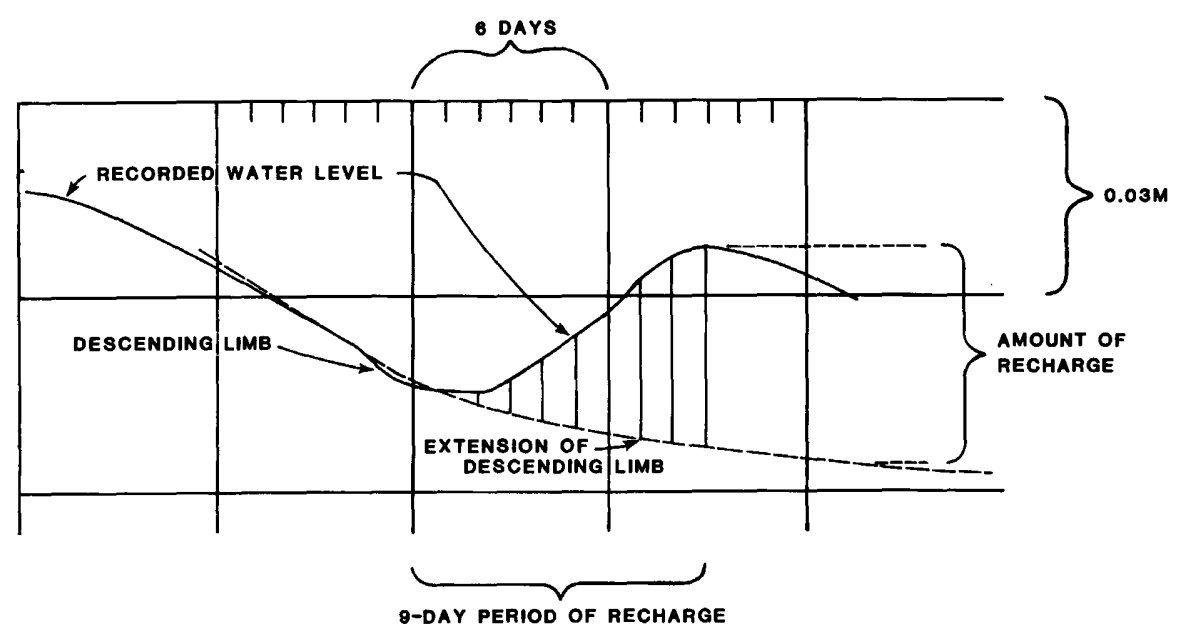

Figure 11.--Graphical method of determining recharge from
observation-well records.

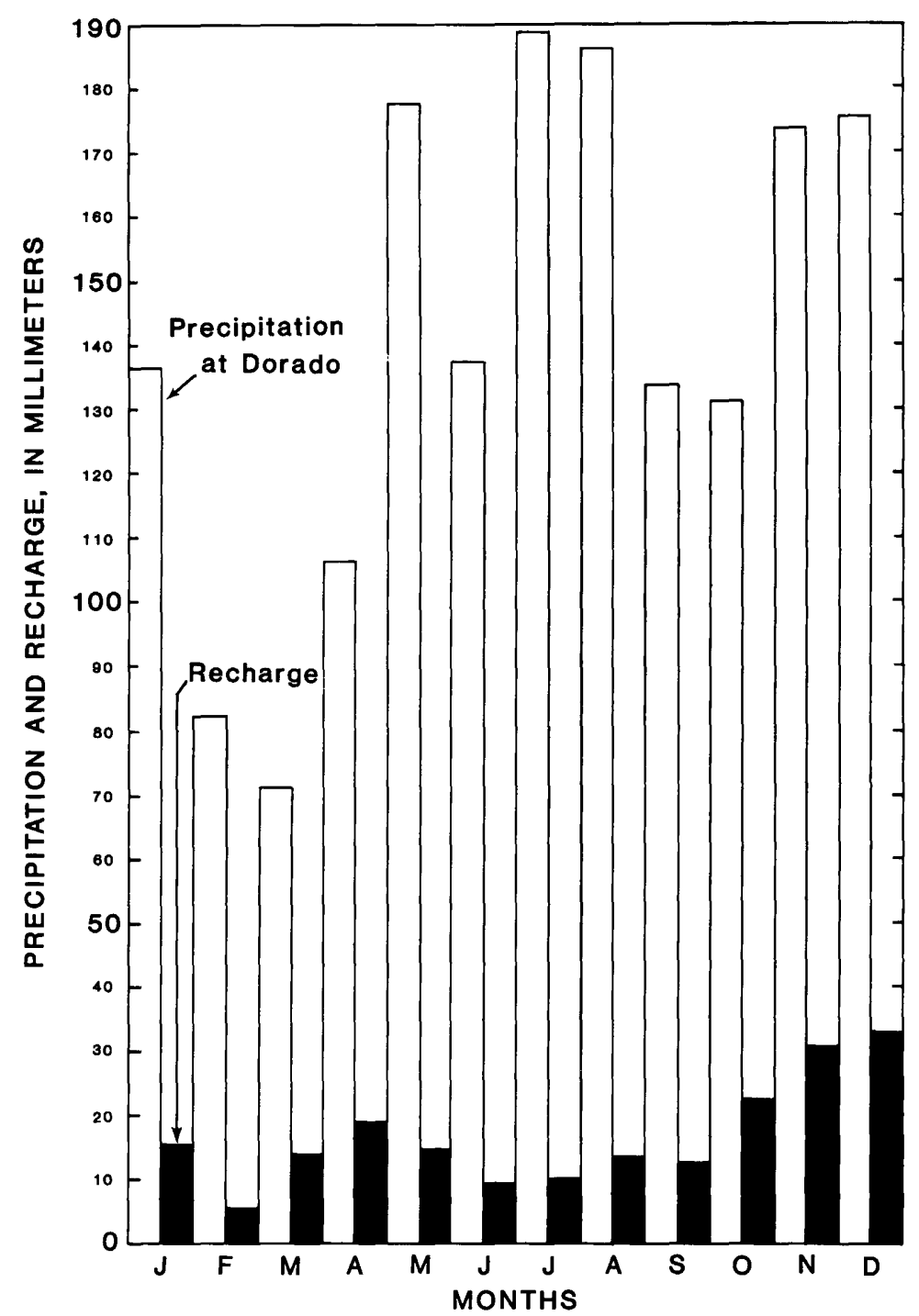

Figure 12.--Variation of average-monthly precipitation and estimated recharge, study area $I$, north central, Puerto Rico. 


\section{HYDROLOGY-Continued}

The storage coefficient of 10 percent may be high. Typical limestones have porosities of from 0.1 to 5 percent (Bosmaci and Sendlein, 1977, Ivankovic and Komatina, 1976, and Torbarov, 1976). However, during the period of record, water levels varied through a range of on $1 \mathrm{y} 2.2 \mathrm{~m}$. Porosity is generally higher in the upper part of watertable aquifers, and it increases as the water level rises (LeGrand and others, 1976). The higher coefficient seemed appropriate.

Recharge was not modeled for the coastal areas east of Arecibo; instead, these areas were considered discharge zones and modeled as such. For those areas between and beyond the basins consj.dered by Giusti and Bennett (1976) in their water-budget study, recharge values for purposes of this model were determined by interpolation or extrapolation of budget -study values for adiacent documented areas.

The areal distribution of recharge values as quantified for this model is shown in figure 13. Also shown are the ground-water discharge zones as defined for the model.

\section{Discharge}

Ocean discharge was considered to occur from both the water-table and artesian aquifers. In the case of the water-table aquifer, the ocean discharge was simulated at the shoreline. Discharge from the artesian aquifers was simulated at the undersea limit (face) of the Cibao Formation and Lares Limestone $30 \mathrm{~km}$ offshore. The location of the termination of the two formations as well as their thickness under the ocean is known from geophysical work performed for the Puerto Rico Water Resources Authority (Western Geophysical and Fugro, 1973). The modeled seaward extension of the Cibao was terminated $10 \mathrm{~km}$ from the shore in the area from north of Río Guajataca to the west end of the model. The Lares was not modeled west of Río Guajataca where recharge probably discharges quickly to the south out of the limestone helt.

\section{Aquifer Boundaries}

One of the special. problems in the modeling of this study area is the definition of artesian aquifer boundaries.

Hypotheses regarding flow in the aquifers were developed by Giusti and Bennett (1976) and reexamined by Giusti (1978), both of whom used a water-budget approach for analysis. Although the nature, and extent of the water-bearing formations have been fairly well identified, several questions about the flow regime have not been answered. For example, does water from the artesian aquifers escape vertically through overlying formations in a near-coastal fault zone and discharge into the Caño Tiburones? Does fresh ground water stored in artesian 


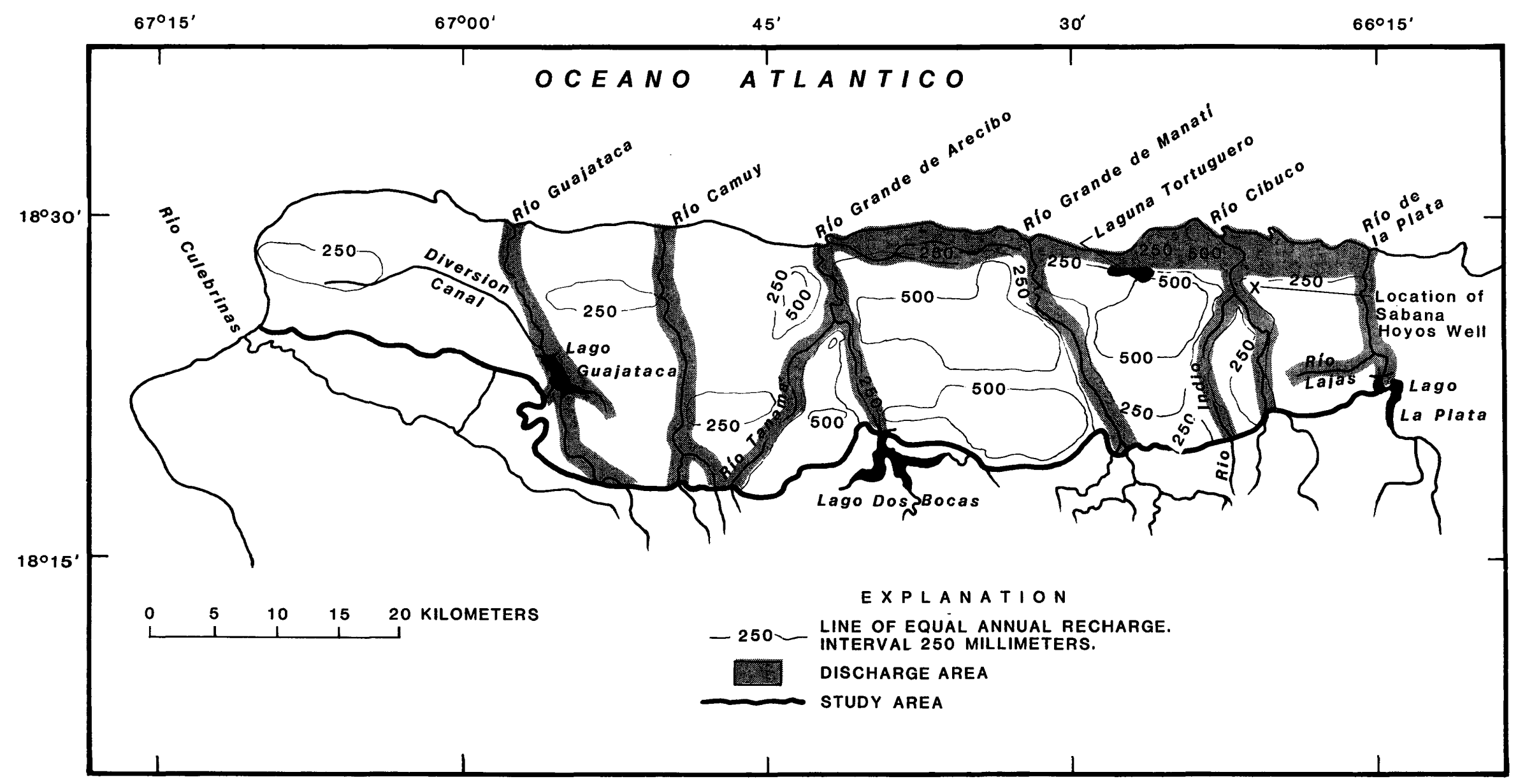

Figure 13.--Simulated recharge and discharge areas. 


\section{HYDROLOGY-Continued}

formations discharge some distance offshore where the formations terminate? Or, is there widespread leakage from the artesian formations through confining beds into the water-table aquifer? The nature of the data is such that some type of model which analyzes all the variables as a system must be used to obtain answers.

Estimates of offshore discharge generally assume that the hydraulic characteristics of the formations do not change and that the hydraulic gradient is the same to the discharge point. However, all well-performance data available indicate variability in the hydraulic characteristics of the Cibao Formation. The wells finished in the Cibao Formation at Cruce Dávila (fig. 4 and table 1) have a greater specific capacity than a well near Barceloneta (number 11). To the east near Manati, wells 12 to 14 are finished in the lares because the Cibao did not yield sufficient water. It is apparent from the geology in the outcrop area that the Cibao becomes tighter to the east. However, it seems that the hydraulic characteristics change to the north also. If this is a general trend then the discharge to the sea will be less than that determined assuming unchanging hydraulic conductivity.
Based on the hydraulj.c gradient observed in the artesian wells and the water levels in the outcrop area, Giusti and Eennett (1976) predicted that the submarine discharge would occur $30 \mathrm{~km}$ offshore.

Broad upward leakage.--
Another possibility for
discharge from the artesian
aquifers is upward leakage
effective over a large area,
perhaps the entire confined
portion of the aquifers. High
pressures in the artesian
aquifers could cause this
leakage. However, the confin-
ing beds are so tight and the
hydraulic conductivity is so
high in the water-table
aquifer that it would be
difficult to measure this type
of flow. In a point of
discharge, such as a well or
in a line of discharge, such
as along a fault, the location
of the discharge can be easily
isolated because there must be
a pressure gradient in the
direction of the point or. line
of discharge. However, where
the discharge is diffused over
a large area, a horizontal
gradient cannot be found even
though there will be a vertical
gradient. The only gradients
observed in the study area are
from the recharge area to the
ocean, across the confining
beds between the water table
and the Cibao, and, to
a lesser extent, between the
Cibao and the Lares. This may
be indicative of upward or
downward leakage depending on
the specific area.
ald
the
Another possibility for discharge from the artesian aquifers is upward leakage effective over a large area, perhaps the entire confined portion of the aquifers. High pressures in the artesian pquifers could cause this ing bed hydraulic conductivity is so high in the water-table aquifer that it would be difficult to measure this type of flow. In a point of discharge, such as a well or as along a fault, the location of the discharge can be easily a pressure gradient in the direction of the point or.line of discharge. However, where the discharge is diffused over a large area, a horizontal gradient cannot be found even gradient. The only gradients observed in the study area are from the recharge area to the ocean, across the confining beds between the water table and the Cibao, and, to a lesser extent, between the Cibao and the Lares. This may downward leakage depending on the specific area. 


\section{MODEL DESIGN AND CHARACTERISTICS}

The theory of analog modeling is described in detail by Freeze and Cherry (1979), and Bennett (1976). The physical makeup of the analog model use in this study is different from the traditional systems. The following description is necessary to understand the model's characteristics.

\section{Hardware}

The model is housed in a metal rack $0.5 \mathrm{~m} \mathrm{x} 0.6 \mathrm{~m} \mathrm{x} 1.9$ m high. Electrical resistors and capacitors are 16 pin DIP (dual in line package) modules. Each module contains 8 resistors and 8 capacitors, isolated within the module. The resistors and capacitors are of equal value within each module; modeled transmissivity (resistors) and storage coefficients (capacitors) represent the average of an 8-note area. The scale of the model is such that averaging has little effect on the results.
DIP modules are connected via appropriate sockets to a printed circuit board which is designed to accept 72 resistor and 24 capacitor modules. Three resj.stor and 1 capacitor modules are connected together to make up 8 nodes on the model, including recharge and discharge isolation. The printed circuit board contains twenty-four 8-node units; 192 nodes if the board is completely filled. A schematic diagram of the connections for an 8 -node unit is illustrated in figure 14. In each of the circuit units, 8 resistors in one DIP module are connected together in series and represent the horizontal component of transmissivity in the east-west direction ( $R_{1}$, to $R_{1}, 8$ in figure 14 )! One end of each of the 8 resistors of the second module $\left(R_{2}, 1\right.$ to $\left.R_{2}, 8\right)$ is connected to a junction of the 8 series resistors of the first module; the other end is connected to the same point in the next circuit unit. These resistors represent the horizontal. component of transmissivity in the north-south direction.

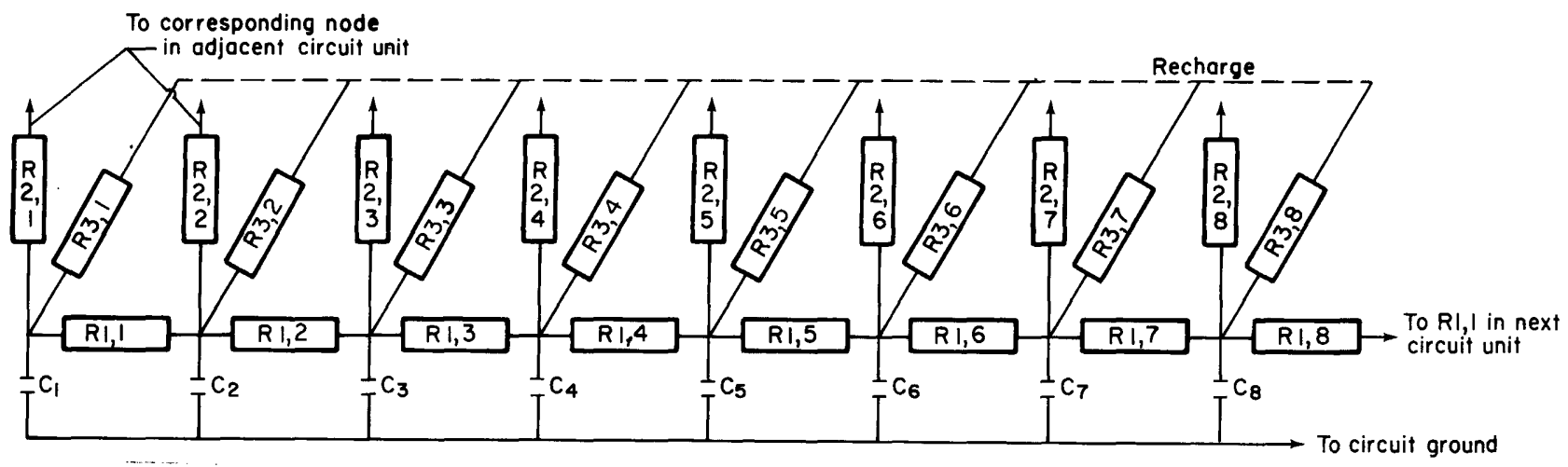

Figure 14.--Schematic of the connections within a circuit unit of 8 nodes. 


\section{MODEL DESIGN AND CHACTERISTICS-Continued}

The third set of resistors in the circuit unit ( $C_{1}$ to $\mathrm{C}_{8}$ ) are connected to the 8 nodes for nonsteady analysis.

There are 21 circuit boards containing the field resistors, 11 for the Aymamón-Aguada aquifer, 5 for the aquifer in the Cibao Formation, and 5 for the Lares aquifer. The Aymamón-Aguada aquifer has more components because the area between Río Cibuco and Río Grande de Arecibo is modeled at 9 times the density of nodes as the rest of the model.

In addition to the 21 circuit boards that model the transmissivity of the aquifers, there are 5 smaller boards that consist of resistors alone that control the recharge to the outcrops. There are 200 recharge circuits or an average of 40 for each of the recharge boards. There are also 2 boards that are used to provide constant voltage sources to simulate water levels for steady-state test of the model.

The recharge component is supplied to a maximum of 8 resistors (nodes) simultaneous1y. Each circuit unit is controlled by one recharge-limiting resistor. Within a group of 8 nodes, one or more resistors might be in a discharge area, in which case only those nodes not discharging are connected to the recharge circuit.

To evaluate the simulated recharge and obtain simulated water levels at the same time, only the recharge circuits are measured. The resistance values of the various circuit elements and the voltage readings from the recharge circuits are fed into a computer. With appropriate programming and unit conversions, the recharge simulation. produces recharge values in millimeters and an average simulated water level in meters for the 8 nodes. There are 200 recharge circuits and 1,535 recharge nodes.

To read the discharge circuits, voltages are measured at both ends of the discharge resistor. These voltages are then fed into a computer where all the pertinent circuit information is stored along with the necessary arithmetic steps and conversion factors. The program then computes the discharge and sums the individua? node discharges for the discharge area which may be a river, swampy area, or lagoon. Pumping is modeled in the same manner.

\section{Conversion Factors}

Factors used for the conversion of resistance and current values were: Head, $3.3 \mathrm{~m} / \mathrm{v}$ (meters per volt); and Flow, $2.8 \times 10^{6}\left(\mathrm{~m}^{3} / \mathrm{d}\right) / \mathrm{amp}$ (cubic meters per dav per ampere).

The size of nodes on the model varies. For the area of both artesian aquifers and most of the water-table aquifer, node centers are separated by $1,524 \mathrm{~m}$; however, in the area of heaviest withdrawal, between the Ríos Cibuco and Arecibo, nodes are separated by 5C8 meters between centers. 


\section{Model Verifjcation}

The reliability of a ground-water model and hence its utility, is demonstrated by verification. If aquifer parameters are modeled using measured or estimated values that are reasonable, and boundary values (input, output) that are an accurate representation of the natural situation, then the degree of similarity between the simulated water levels and the actual water levels is a measure of the reliability of the model.

\section{Steady-State Simulation}

Recharge according to table 3 and discharges from table 5 were simulated on the model.
Adjustments were made to simulate recharge, discharge, and resistance values until a reasonable match was obtained between the generalized water-table configuration of figure 9 and the simulated water levels. Summaries of the adjusted simulated recharge and discharge values are reported in tables 6 and 7 . Pumping from the water-table aquifer at a rate of 1.36 $\mathrm{m} / \mathrm{s}$ was simulated for this exercise. Pumping was not simulated from the artesian aquifers for the steady-state demonstration; instead original heads were modeled. There was no attempt to contour pressure heads in the artesian formations but where they were known, heads at specific places were compared with those obtained by simulation in order to evaluate assumptions about boundary conditions.

Table 6.--Ground-water flow from discharge areas.

\begin{tabular}{|c|c|c|c|c|c|}
\hline & & $C \cup B \backslash C$ & METER 8 & PER SEC & OND \\
\hline & DISCHARQE AREAS & & $\begin{array}{l}\text { FROM } \\
\text { AYMAMON } \\
\text { AND } \\
\text { AGUADA } \\
\text { LIME- } \\
\text { STONES }\end{array}$ & $\begin{array}{c}\text { FROM } \\
\text { CIBAO } \\
\text { FORMATION }\end{array}$ & $\begin{array}{l}\text { FROM } \\
\text { LARES } \\
\text { LIMESTONE }\end{array}$ \\
\hline 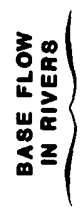 & $\begin{array}{l}\text { Río de la Plata (I.ajas) } \\
\text { Río Cibuco (Indio) } \\
\text { Laguna Tortuguero } \\
\text { Río Grande de Manatí } \\
\text { Río Grande de Arecibo (Tanamá) } \\
\text { Río Camuy } \\
\text { Río Guajataca }\end{array}$ & $\begin{array}{r}0.54 \\
.78 \\
.46 \\
1.68 \\
2.67 \\
1.04 \\
.42\end{array}$ & & & \\
\hline 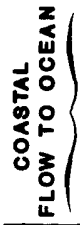 & $\begin{array}{l}\text { From Río de la Plata to Río Cibuco } \\
\text { Río Cibuco to Río de Manatí } \\
\text { Río Grande de Manatí to } \\
\text { Río Grande de Arecibo (Tiburones) } \\
\text { Río Grande de Arecibo to Río Camuy } \\
\text { Río Camuy to Río Guajataca } \\
\text { Río Guajataca to west coast }\end{array}$ & & $\begin{array}{r}.57 \\
.53 \\
\\
2.04 \\
.29 \\
.13 \\
.20\end{array}$ & $\begin{array}{l}0.08 \\
.024 \\
.24 \\
.047 \\
.028 \\
.014\end{array}$ & $\begin{array}{l}0.02 \\
.006 \\
.004 \\
.016 \\
.016 \\
--\end{array}$ \\
\hline
\end{tabular}




\section{MODEL DESIGN AND CHARACTERISTICS-Continued}

\author{
Reasonable conformity \\ between the recharge and \\ discharge data produced by the \\ model and those developed in \\ previous water-budget studies \\ assured that the model was \\ operational except for the \\ determination of boundary \\ conditions and the storage \\ coefficient of the Cibao \\ aquifer.
}

\section{Testing of Boundaries}

The model was used to

help determine whether or not

the coastal fault postulated

by Briggs (1961) exists.

Resistors were placed to

approximate the existence of

the fault between the Cibao

and the Aymamón-Aguada

aquifers for the $15 \mathrm{~m}$ from

Barceloneta to Arecibo

simulating a $100-\mathrm{m}$ wide

permeable zone through the

150-m confining bed. The results indicated that if the vertical conductivity were as

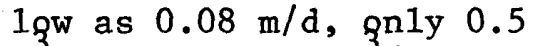
$\mathrm{m}^{3} / \mathrm{s}$ of the $3.1 \mathrm{~m}^{3} / \mathrm{s}$ of freshwater discharging in the area would come from the Cibao. Furthermore, this flow out of the Cibao Formation would lower the head in the Cibao by $36 \mathrm{~m}$. The new pressure head would not be consistent with the observed heads in that aquifer. Similarly, if the vertical hydraulic conductivity in the fault zone were $0.008 \mathrm{~m} / \bar{d}$, on $1 \mathrm{y} 0.14 \mathrm{~m}^{3} / \mathrm{s}$ would come from the Cibao. Again, there would be a drop of approximate1y $10 \mathrm{~m}$ in the pressure heads which would not compare well with observed values. Water levels in the water-table aquifer would rise an average of $0.35 \mathrm{~m}$ under the first assumption of conductivity and $0.15 \mathrm{~m}$ under the second.

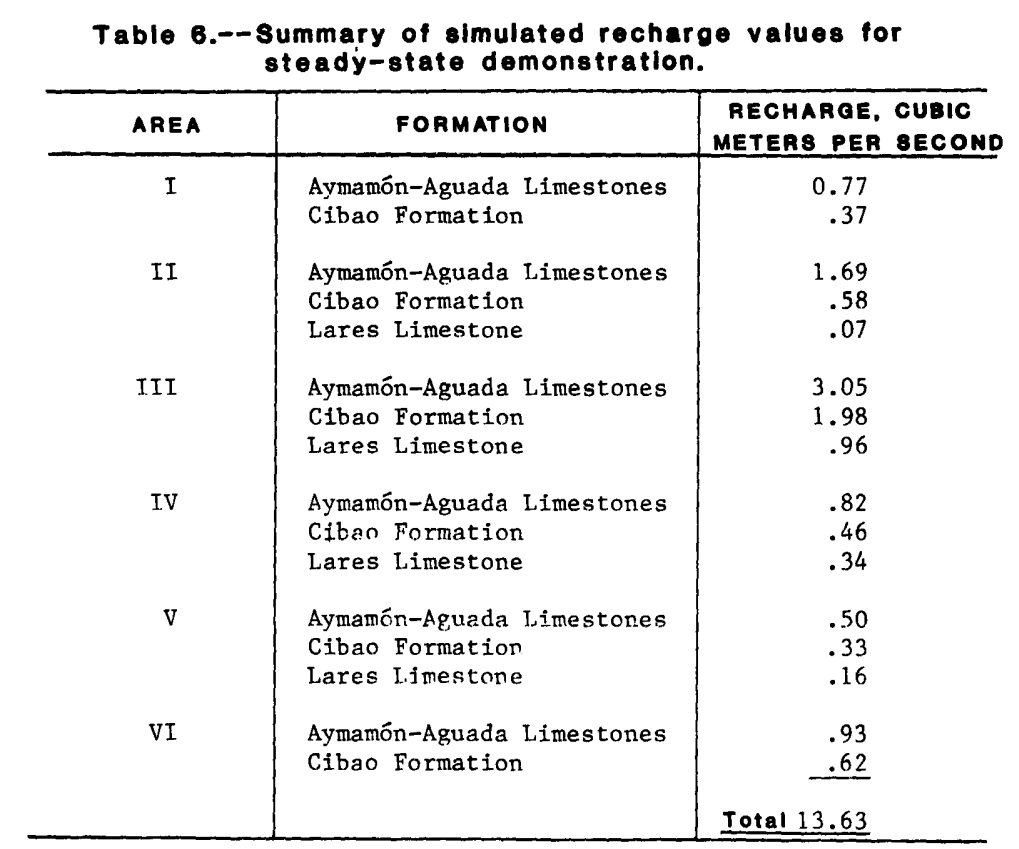


Table 7.--Simulated discharge values for steady-state demonstration.

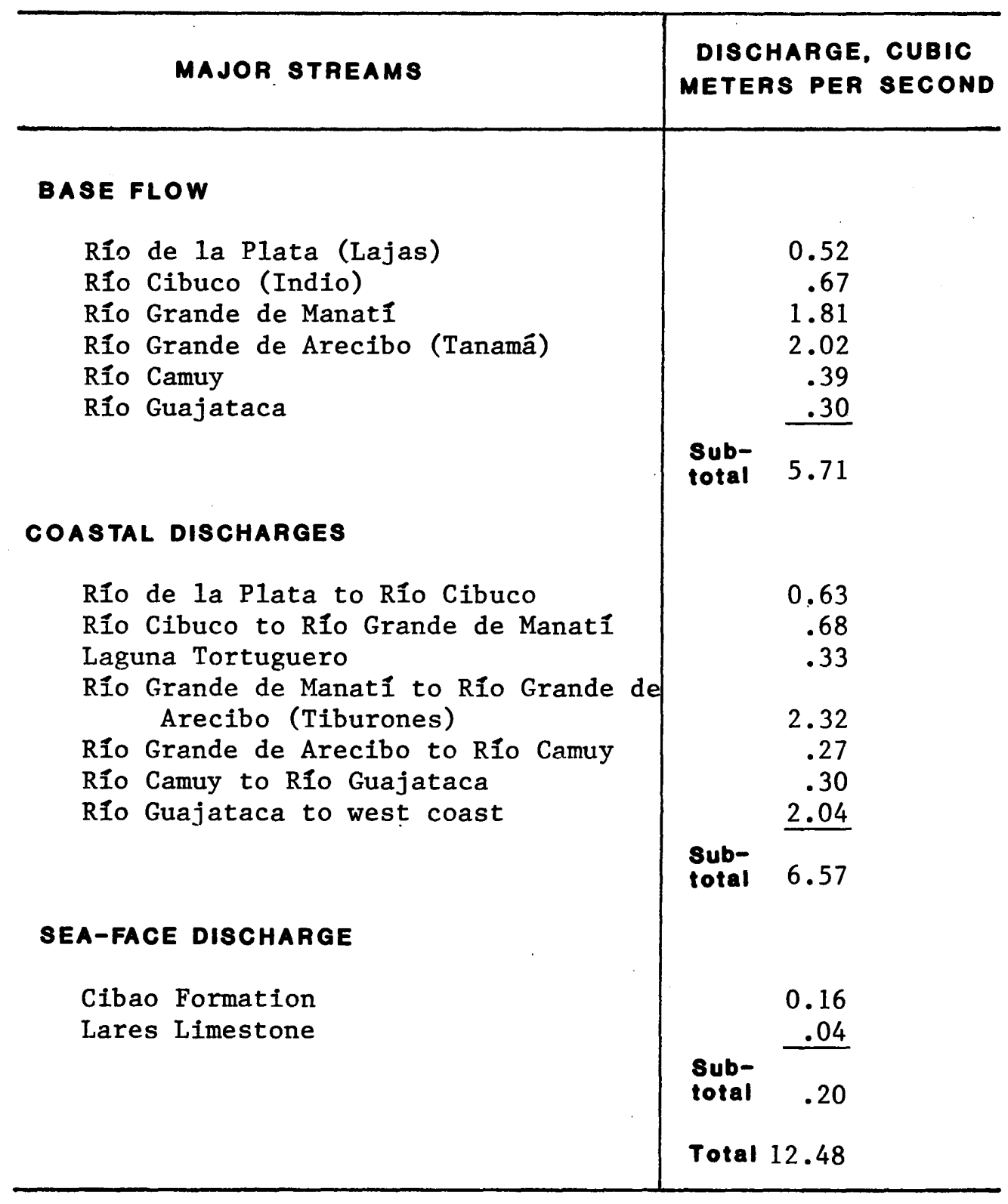




\section{MODEL DESIGN AND CHARACTERISTICS-Continued}

The condition was also simulated for one-half the distance from Barceloneta to Arecibo. In this case, a simulated $0.08 \mathrm{~m} / \mathrm{s}$ escaped the Cibao and the pressure head in the Cibao was about 4 $m$ lower than the observed field value.

If a fault with the displacement suggested does exist in the area, it must also affect the discharge in the Lares Limestone. From drillers' records it appears that the upper confining bed for the Lares aquifer is approximate1y $60 \mathrm{~m}$ thick. Under these conditions and with a vertical hydraulic conductivity of $0.0034 \mathrm{~m} / \mathrm{d}$, the modeling exercise indicates that $0.06 \mathrm{~m} / \mathrm{s}$ will flow from the Lares to the Cibao and heads in the Lares will drop by approximately $20 \mathrm{~m}$; again, contrary to field observations.

This analysis demonstrates that, whatever other evidence there is for a fault along the coast, the amount of water discharging in this swampy region is not valid evidence for the fault. Water-budget analyses using analog model simulation indicate that only an insignificant amount is available from the artesian formation in this area. Even this small quantity would cause water levels in the artesian zone to be lower than those observed.
This analysis does not preclude the possibility that there is some untested area that has the proper characteristics to allow a concentrated flow of water to escape from the artesian aquifers if the fault exists. One area that could have a major effect on the water budget, but for which no data are available, is the area west of the postulated fault to the Rio Grande de Arecibo.

Other possible discharging boundaries are the undersea faces of the artesian aquifers. When the pressure head necessary to produce discharge at these faces was simulated on the model, the resulting discharges were $0.16 \mathrm{~m} / \mathrm{s}$ from the Cibao Formation and $0.039 \mathrm{~m} / \mathrm{s}$ from the Lares Limestone. Previously, these discharge had been estimated at $0.52 \mathrm{~m}^{3} / \mathrm{s}$ from the Cibao and $0.075 \mathrm{~m} / \mathrm{s}$ from the Lares aquifer (Giusti, 1978, table 1).

There is reason to believe that the artesian aquifers are continuous, even though the hydraulic conductivity may vary. Thus the inclusion of this undersea boundary is in harmony with the other concepts used to model the limestones. Although it is probable that there is freshwater stored under the ocean, this resource may not be economical to develop because of decreasing hydraulic conductivity. 


\section{MODEL DESIGN AND CHARACTERISTICS-Continued}

Broad upward leakage of water from the Lares Limestone and Cibao Formation was simulated as taking place between the artesian aquifers and between the Cibao and the water-table aquifers. The hydraulic conductivity between the upper two formations is simulated at $10^{-5} \mathrm{~m} / \mathrm{d}$ and that between the Lares and Cibao as $5 \times 10^{-6} \mathrm{~m} / \mathrm{d}$. This supposition was invalidated because, at the resulting rate of leakage, the simulated heads in the Cibao dropped to a level below that which has been observed in the aquifer. However, because there was little difference between the heads in the Lares and Cibao aquifers and because no significant change in heads in the Lares was detected with the addition of this leakage between these two aquifers, the leakage between the artesian aquifers was assumed probable. The system is presently modeled with no hydraulic connection between the Cibao and the water-table aquifer, and with a simulated semiconfining layer $60 \mathrm{~m}$ thick with a hydraulic conductivity of $5 \times 10^{-6} \mathrm{~m} / \mathrm{d}$ between the Lares and Cibao aquifers.

\author{
Pumping Simulation \\ in the Cibao Aquifer
}

In order to determine the storage coefficient that should be used to represent conditions in the Cibao aquifer, the model was used to simulate the withdrawals that have been made from that formation at an array of wells near Cruce Davila (fig. 4). Average withdrawals and the duration of withdrawals for each of the 9 wells used in the simulation are listed in table 8. Data were provided by the Puerto Rico Department of Natural Resources (personal communication). Although some wells may allow leakage of water from the artesian aquifers into the water-table aquifer, the simulation assumed that all wells were extracting for the full 5- or 9-year pericd shown. The reasoning was that proper selection of a storage coefficient would produce a pressurehead decline such as that shown in figure 5 for well 10a. However, it was not possible to produce such a decline under the stress of the pumping shown in table 8 , no matter what storage coefficient was modeled. The simulated decline was much less than that shown in figure 5 .

Table 8.--Cibao aquifer pumping simulation data.

\begin{tabular}{c|c|c}
\hline $\begin{array}{c}\text { WELL NUMBER } \\
\text { (fig. 5) }\end{array}$ & $\begin{array}{c}\text { AVERAGE WITHDRAWAL } \\
\text { RATE, m } \mathbf{3} / \mathbf{8}\end{array}$ & $\begin{array}{c}\text { YEARS } \\
\text { OF RECORD USED }\end{array}$ \\
\hline 1 & 0.031 & 9 \\
2 & .007 & 5 \\
3 & .022 & 5 \\
4 & .011 & 5 \\
5 & .035 & 5 \\
6 & .022 & 9 \\
8 & .007 & 9 \\
9 & .027 & 9 \\
11 & .009 & 5 \\
\hline
\end{tabular}




\section{MODEL DESIGN AND CHARACTERISTICS-Continued}

\author{
What could cause this \\ apparent inconsistency? The \\ transmissivity could be in \\ error, but if so the transmis- \\ sivity must be lower than \\ modeled to produce the proper \\ drawdown. In the steady state \\ only 30 percent of the expected \\ seaward flow was modeled to \\ achieve a match to original \\ water levels. If the trans- \\ missivity were lower, then \\ there would be less flow to \\ the sea and the water budget \\ would differ from observed \\ conditions. The nature of the \\ limestone aquifers could \\ affect the drawdown, in that \\ solution channels commonly \\ develop, and there could be a \\ separation of the observation \\ we11 from the channel in which \\ most of the withdrawal is \\ taking place. This does not \\ seem correct because every \\ we11 that has been drilled \\ into the Montebe110 Member of \\ the Cibao was initially \\ flowing. Although it is \\ possible there was greater \\ pumpage from the aquifer than \\ that modeled, the amount of \\ water withdrawn for use is \\ reasonably accurate. \\ Probably the drawdown \\ could not be obtained in the \\ simulation because the water \\ level in observation wel1 10 \\ is affected by water escaping \\ into the water table aquifer. \\ It appears that significant \\ amounts of artesian water are \\ escaping from some of the \\ older wells before reaching \\ the surface of the ground. \\ This phenomenon has been \\ observed in one of the newer \\ we11s. About $0.02 \mathrm{~m}^{3} / \mathrm{s}$ was \\ escaping from well 12 (fig. 4)
}

which is an open hole in both the Cibao Formation and Lares Limestone. Two other wells ( 1 and 4) have been abandoned because of loss of pressure at the surface.

Storage coefficient for the model was based on an estimate of $0.3 \times 10^{-6}$ per meter of thickness of the aquifer (Lohman, 1972, p. 53). The Cibao is $300 \mathrm{~m}$ thick in the area of artesian flow. Therefore, $\mathrm{S}$ was ${ }_{6}$ estimated at $300 \times 3.28 \times 10^{-6}$ or about $10^{-3^{x}}(0.001)$ for model

purposes.

\section{Model Simulation}

\author{
After applying the \\ simulated recharge, discharge, \\ transmissivity, and storage \\ coefficient to the model as \\ previously described, and \\ determining that the artesian \\ discharge boundaries were \\ offshore, simulated heads were \\ computed and plotted on the \\ base map. The simulated water \\ levels in the water-table \\ aquifer obtained from the \\ steady-state model run are as \\ shown in figure 15 (compare \\ with fig. 9). \\ The model simulates \\ ground-water conditions \\ reasonably well in the area \\ east of the Río Grande de \\ Arecibo, where hydrologic data \\ are relatively abundant. \\ Because of the relative lack \\ of information west of the Rio \\ Grande de Arecibo, the model \\ cannot be verified for that \\ part of the study area. In \\ both areas the model can be
}




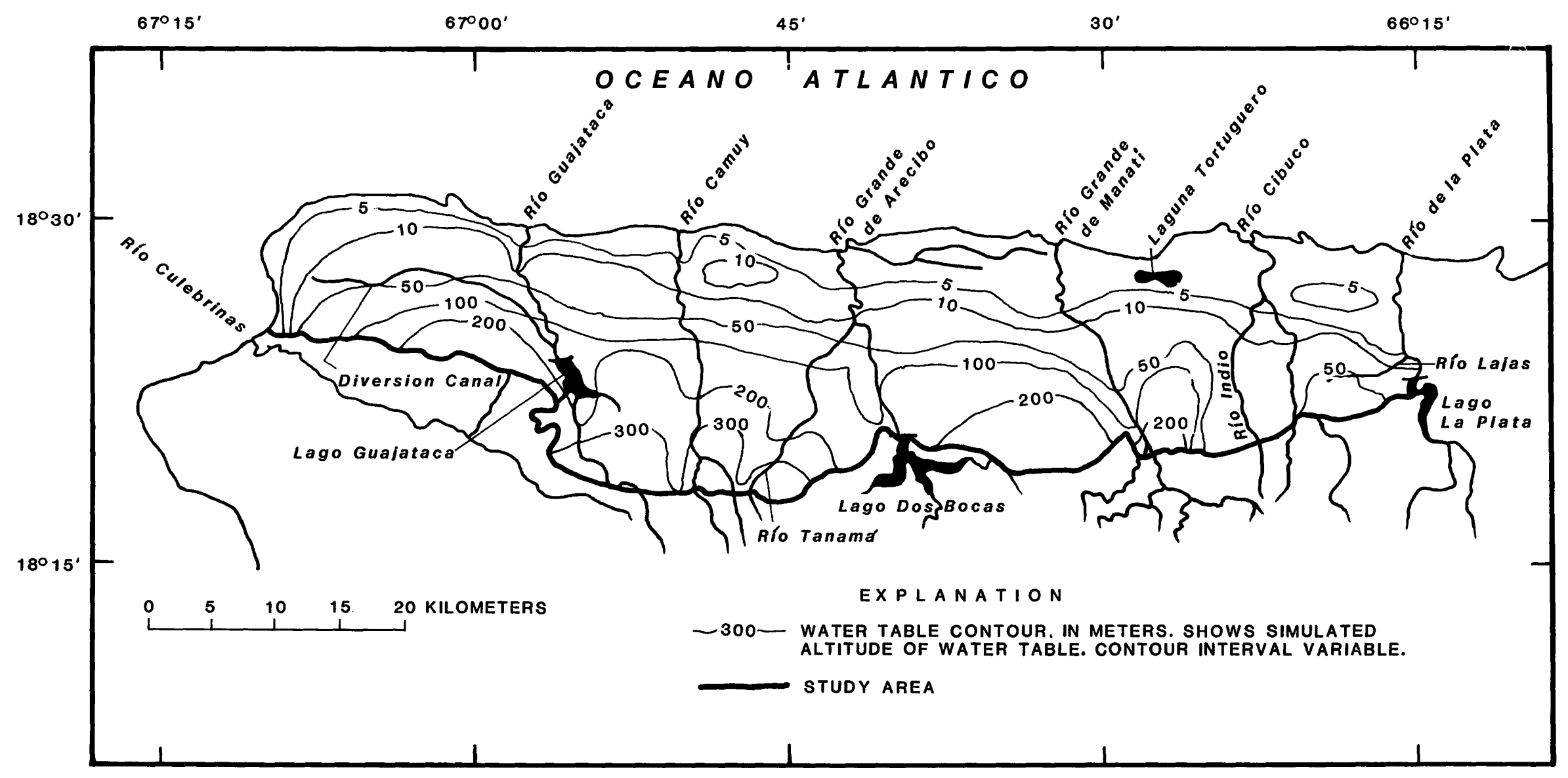

Figure 15.--Simulated water-table for model demonstration. 


\section{MODEL DESIGN AND CHARACTERISTICS-Continued}

used until such time that data are available to indicate the need for updating the model.

The total simulated ground-water discharge from the study area amounts to about $12 \mathrm{~m}^{3} / \mathrm{s}$ (table 7). On the basis of head gradients, aquifer thickness and hydraulic conductivity, Giusti. (1978, table 1) estimated the total $1_{3}$ ground-water flow to be $4.6 \mathrm{~m} / \mathrm{s}$. In contrast, the total base flow of the limestone basins (his table 3 ) was calculated as about $11 \mathrm{~m}^{3} / \mathrm{s}$, a figure that considers both the Tortuguero and Tiburones discharges as base flow. By their nature, they would be included in the total through the aquifers. Removing the 3 $\mathrm{m} / \mathrm{s}$ calculated for these two features leaves a base flow of $8 \mathrm{~m} / \mathrm{s}$. Giusti points out that the rainfall for the year for which base flow figures were calculated was approximately 20 percent above average; therefore the base-f! ow figures were correspordingly high. Assuming that the base flow is affected by the higher annual rainfall and is 20 percent high, the average base flow 3 would approximate $6.7 \mathrm{~m}^{3} / \mathrm{s}$ for the rivers included in Giusti's analysis. He did not include the lower Río de la Plata, but assuming characteristics similar to the Cibuco, a base flow of $0.3 \mathrm{~m} / \mathrm{s}$ can be assigned to the Río de $1 a$ Plata giving a total of 7 $\mathrm{m} / \mathrm{s}$ for all the rivers.

The potential coastward flow through the aquifers is not expected to change significantly with the variation in 38 rainfall; therefore the total discharge (base flow plus coastal discharge) would be about $11.6 \mathrm{~m} / \mathrm{s}$, close to the amount simulated.

Giusti reports (1978 tąbles 1 and 3 ) about 8.1 $\mathrm{m}^{3} / \mathrm{s}$ discharging east of the Río Grande de Arecibo, close to the amount simulated $(8.4 \mathrm{~m} / \mathrm{s}$, if the Río de la Plata is included).

The model can be used to evaluate some long range ground-water development and management plans, but is not sufficiently detailed to simulate the performance of individual wells or resultant interference effects. Subsequent sections of this report describe the results of selected planning problems that were simulated on the model. The exercises were limited to the eastern half of the study area where more complete data were available for verification.

\section{Modeling Exercises}

The model was used to provide answers to three questions regarding the effects of. water supplies in the area near Barceloneta. First, a nonsteady-state simulation of withdrawal of $0.44 \mathrm{~m} / \mathrm{s}$ (10 million gallons per day) from the water-table aquifer was made to forecast potential waterlevel changes; second, a steady-state simulation was programmed to determine the maximum amount of water that can be withdrawn from the water-table aquifer under 


\section{MODEL DESIGN AND CHARACTERISTCS-Continued}

average recharge conditions; and third, nonsteady-state simulations were made to demonstrate the effect of withdrawal of $0.44 \mathrm{~m}^{3} / \mathrm{s}$ from the artesian aquifer in the Cibao Formation after 90 vears and 160 years of pumping.

$$
\begin{gathered}
\text { Simulation of Withdrawal } \\
\text { of } 0.44 \mathrm{~m}^{3} / \mathrm{s} \text { from }
\end{gathered}
$$

the Water-Table Aquifer

To describe the drawdown of the water-table aquifer resulting from a withdrawal of $0.44 \mathrm{~m}^{3} / \mathrm{s}$ for a short period of years, a nonsteady-state simulation was made. Current was withdrawn from 38 nodes on the mode1, simulating a widespread pattern of pumping, in the area indicated on figure 16 extending west $10 \mathrm{~km}$ from Cruce Dávila, varying in width from 0.5 to $1.5 \mathrm{~km}$, with one area $0.5 \times 0.5 \mathrm{~km}$ approximately $1.5 \mathrm{~km}$ south of the center of the larger pumping area. The resulting drawdown are those that would result after 2. years of pumping assuming a storage coefficient of 0.1 . For a larger storage coefficjent these drawdowns would occur later (that is, after 3 years for $S=0.15$; and 4 years for $S=0.2$ ). Drawdown would be greater in the vicinity of the pumping wells themselves, about $2 \mathrm{~m}$ greater than the average for the nodes represented in figure 16.

The amount of water that would be diverted from the total presently discharging in the Caño Tiburones would be minimal, about 5 percent of the water now pumped from the
Caño. The amount estimated to be taken from storage was 7.6 million $\mathrm{m}^{3}$, or 3 at an average rate of $0.12 \mathrm{~m}^{3} / \mathrm{s}$ for 2 years (about 27 percent of the amount pumped). The other 68 percent of the water pumped would come from induced recharge in areas adjacent to the pumping area.

Other factors that would affect the water levels were not modeled because their influence is not known. For example, recharge from rainfall in the area can be expected to increase under the influence of pumping because the lowering of the water levels creates a gradient steeper than the natural gradient and recharge that would normally move out of the area would be expected to move toward the pumping area.

\section{Simulation of Long-Term Withdrawal from the Water- Table Aquifer}

A steady-state model run was made to determine how much water could be pumped from the water-table aquifer in the Caño Tiburones area between Arecibo and Barceloneta without reversing the hydraulic gradient. A reversal of the hydraulic gradient might cause seawater encroachment southward into the area.

Present1y, large quantities of fresh water $\left(3.2 \mathrm{~m}^{3} / \mathrm{s}\right.$, or $74 \mathrm{Mgal} / \mathrm{d}$ ) are being pumped. to the ocean from the Caño Tiburones. Approximately half of this water is groundwater discharge from the water-table aquifer. The 


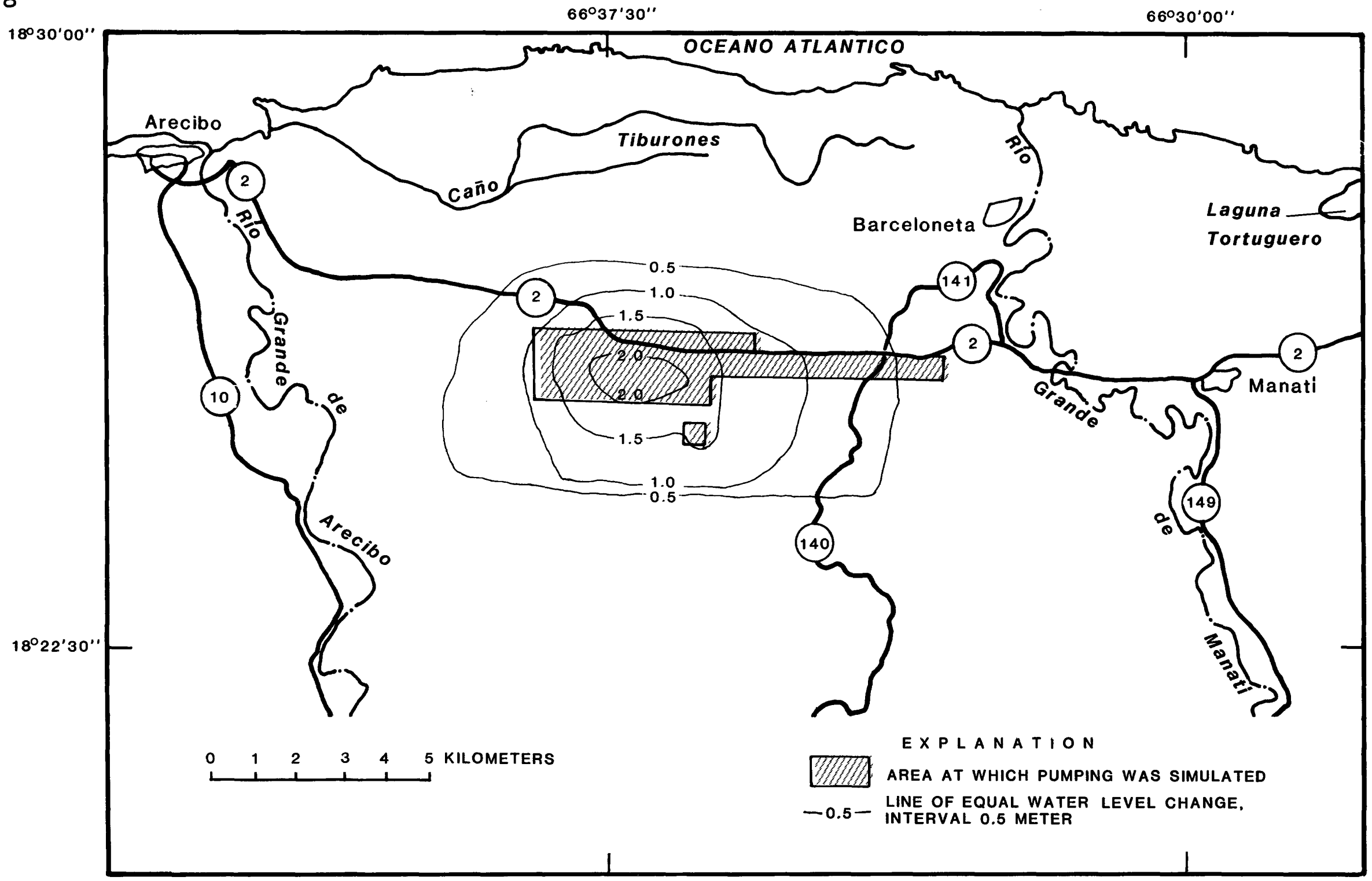

Figure 16.--Water-level change resulting from simulated pumping an additional 0.44 cubic meters per second from water-table aquifer. 


\section{MODEL DESIGN AND CHARACTERISTICS-Continued}

other half is probably derived as under flow from the Arecibo and Manati rivers. It is assumed that all ground-water discharge from the water-table aquifer between Arecibo and Barceloneta enters the Caño Tiburones and there is no ground-water contribution from the two rivers.

The water table is modeled as a single-layer aquifer. Heads along a line paralle1 to the ocean shore at the southern edge of the discharging area were noted from the demonstration exercise (the 5-meter coritour of figure 15). Current was withdrawn from the network at three points about equally spaced between the simulated Río Grande de Arecibo and Río Grande de Manati. These were adjusted so that the drawdowns along the southern edge of the discharge area were nearly, but not quite, equal to the original heads. The drawdowns approached the original heads only at the points just north of the simulated withdrawal points. In other places the drawdowns were less, indicating that there would still be water flowing to the discharge area. The simulated discharges were $0.53,0.52$, and $0.58 \mathrm{~m} / \mathrm{s}$ (or a total of $1.6 \mathrm{~m} / \mathrm{s}$, or 37 Mgal/d), respectively. The three simulated pumping points and the resulting drawdowns for this experiment are shown in figure 17.

Because this is a steadystate condition, none of the water could be thought of as coming from storage. Instead, the water withdrawn will come from a reduction in the amount of water flowing to the sea $\left(1.06 \mathrm{~m}^{3} / \mathrm{s}\right)$, and induced recharge from the Rio Grande $^{\circ}$ de Manatí $\left(0.20 \mathrm{~m}^{3} / \mathrm{s}\right)$ and the Pío 3 Grande de Arecibo $\left(0.11 \mathrm{~m}^{3} / \mathrm{s}\right)$; the remainder is contributed from increased flow into the area from the south $(0.23 \mathrm{~m} / \mathrm{s})$.

\section{Simulation of Increased Withdrawal from the Cibao Formation}

To evaluate the ability of the artesian aquifer in the Cibao Formation to supply water to wells on a long-term basis, pumping from 9 existing we11s was simulated at more than double the rates presently in effect. Simulated exercises withdrawing 0.44 $\mathrm{m}^{3} / \mathrm{s}$ (10 Mgal/d) were accomplished for periods of 90 and 160 years. In both of these simulations the drawdown reached a maximun, then leve? off before the end of the period. The pumping. was distributed according to table 8. The greatest drawdown simulated in both exercises was just over $50 \mathrm{~m}$, meaning that artesian heads would still be $50 \mathrm{~m}$ above the water table.

The aquifer storage coefficient simulated for these exercises was 0.001 . The drawdowns did extend back updip into the outcrop area where the storage coefficient was simulated at 0.1 . The total amount of water recovered from storage affer 90 years was $61 \mathrm{x}$ $10^{6} \mathrm{~m}^{3}$, and that recovered after 160 years was $85 \mathrm{x}$ $10 \mathrm{~m}$. The proportion 


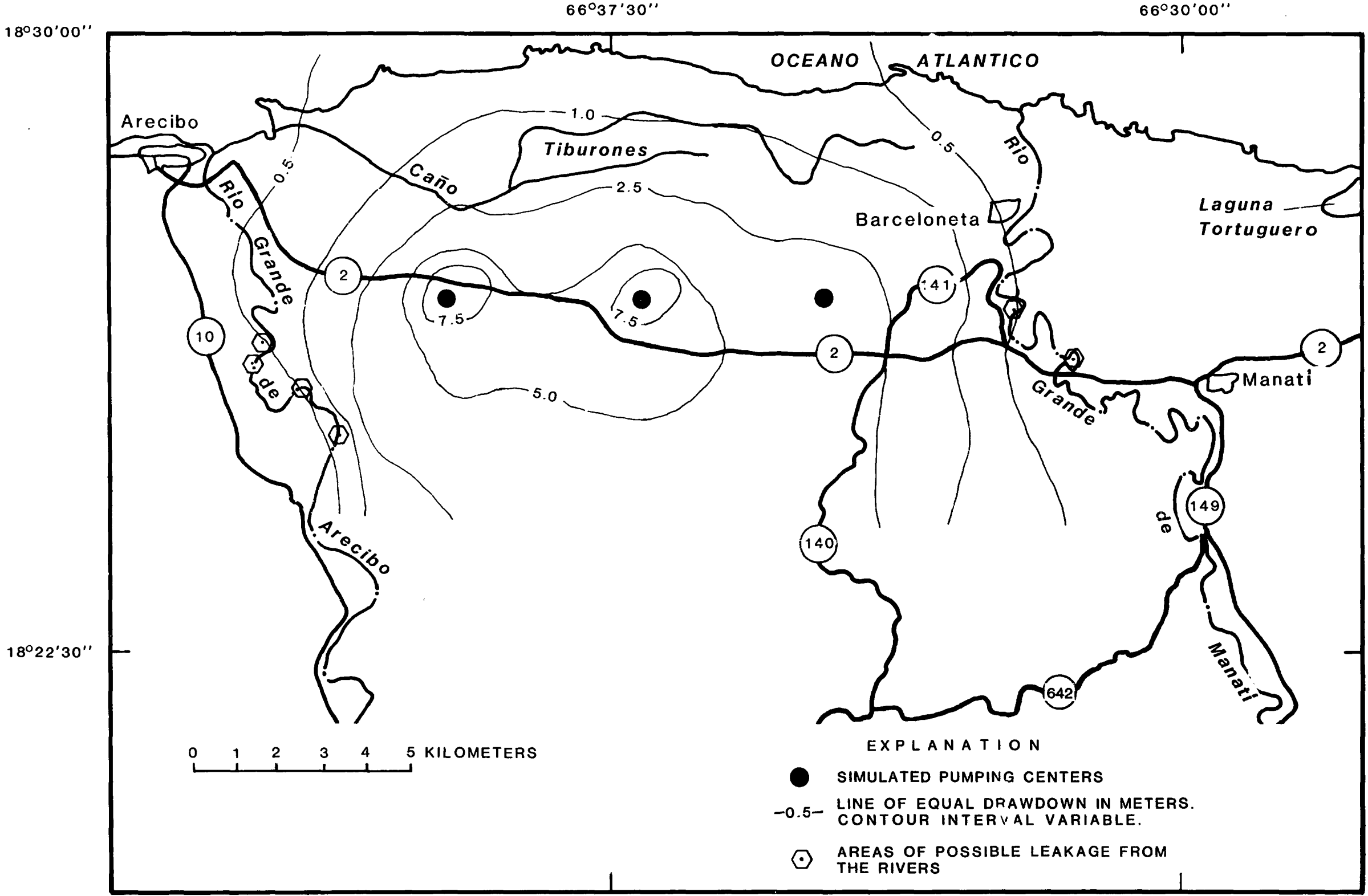

Figure 17.--Simulated drawdown of water-table aquifer for 1ong-term water withdrawal of 1.6 cubic meters per second. 


\section{MODEL DESIGN AND CHARACTERISTICS-Continued}

of total water pumped that came from storage was about 6 percent for 90 years and 4 percent for 160 years. The remainder came from induced recharge in the outcrop area. There are no rivers to recharge the artesian aquifer except for some distance away in the outcrop where the formation is in contact with the surface streams.
Figures 18 and 19

indicate the maximum artesian pressure changes expressed in terms of drawdown in meters for the 90- and 160-year artesian pumping problems.

The simulation indicates that it will be ${ }_{3}$ possible to withdraw $0.44 \mathrm{~m}^{3} / \mathrm{s}$ from the Cibao Formation indefinitely.

\section{CONCLUSIONS}

The north coast limestone belt includes three significant aquifer units, two of which are artesian. The uppermost unit, and the most heterogeneous of the three, is commonly referred to as the water-table aquifer and consists of the Aymamón and Aguada Limestones and various unconsolidated sediments. The most prolific of the two artesian zones is the Montebello Limestone Member of the Cibao Formation. The Iares Limestone, lowest stratigraphically, is the least permeable of the three but it is still important as an aquifer. Transmissivities estimated from single-well pumping tests ranged widely, from 3 to $100,000 \mathrm{~m}^{2} / \mathrm{d}$.

Two distinct hydrologic areas, approximately equal in size, exist in the limestone zone. These are the area west of the Río Grande de Arecibo which receiyes recharge of about $4.5 \mathrm{~m}^{3} / \mathrm{s}$, and the area east of the same river, which receives double that recharge despite similar climatic conditions.
Recharge to the artesian aquifers is estimated at 5.8 $\mathrm{m} / \mathrm{s}$. Present pumping from the artesian zones is about $0.2 .3 \mathrm{~m} / \mathrm{s}$, while pumping from water-table aquifer is about $1.4 \mathrm{~m}^{3} / \mathrm{s}$.

An electrical analog model simulated observed water levels satisfactorily on a steady-state basis when programmed with available estimates of recharge and discharge. Original artesian pressures observed in the confined aquifers were used to determine the probable magnitude and location of the natural discharge from the Cibao Formation. The influence of a suspected fault could not be verified by simulation of the condition on the analog model, casting doubt on its existence. The model was also used to support the theory that the discharge from the artesian aquifers occurs at considerable depth below sea level some $30 \mathrm{~km}$ north of the coastline. 


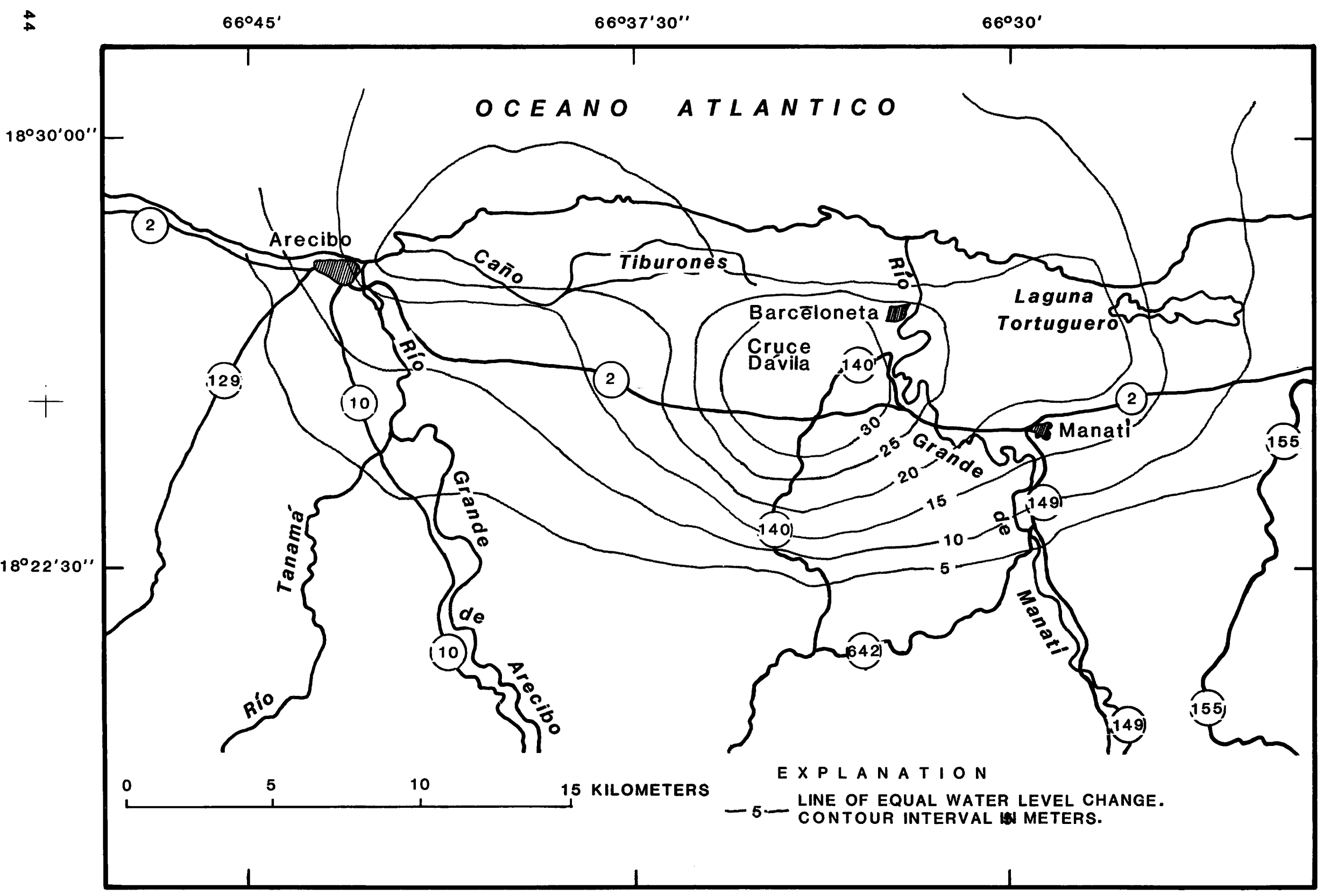

Figure 18.--Simulated water level changes after pumping 0.44 cubic meters per second for 90 years from the artesian aquifer in the Cibao Formation. 


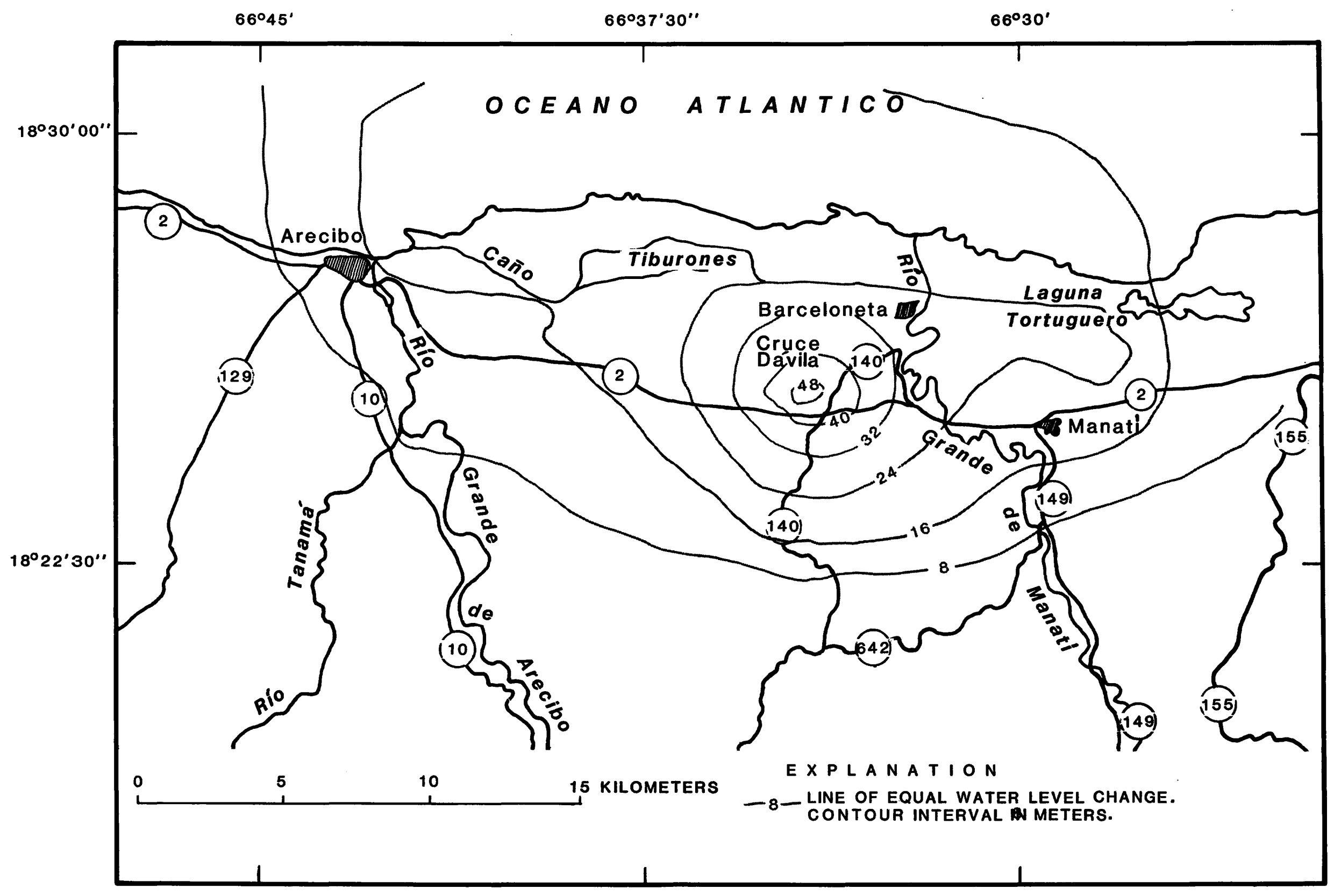

Figure 19.--Simulated water leve1 changes after pumping 0.44 cubic meters per second for 160 years from the artesian aquifer in the Cibao Formation. 


\section{CONCLUSIONS-Continued}

Declining pressure levels in an observation well open to the Cibao Formation are

greater than those which might be produced by present pumping rates from an aquifer with characteristics of the Cibao. It is assumed that a significant amount of water from abandoned artesian wells is leaking into the water-table aquifer, and because the water table is more than $60 \mathrm{~m}$ below the land surface, the pressure drop will be greatest at or near the leaking abandoned wells.

3 The pumping of 0.44 $\mathrm{m}^{3} / \mathrm{s}$ from the water-table aquifer and from the Cibao aquifer was simulated under nonsteady conditions to determine drawdown effects. In each case the withdrawal rate was possible. Maximum drawdowns were $4.2 \mathrm{~m}$ in the water-table aquifer simulation and $50 \mathrm{~m}$ in the test of the artesian aquifer. The maximum drawdown in the artesian aquifer was the same after 160 years of simulated pumping as it was after 90 years, indicating that steady-state analysis was sufficient to evaluate effects.

In a steady-state simulation test of the water-table aquifer, withdrawal was simulated at three sites south of Caño Tiburones. Discharge was increased until flow to the Caño was reduced to near zero in the area just north of the pumping sites. Using just these three simulated pumping sites, $1.6 \mathrm{~m}^{3} / \mathrm{s}$ could be withdrawn without completely cutting off flow to the Caño area.

More versatile analysis of the effects of variable well depth and spacing can be done with a model having closer grid spacing and multiple layers. These factors are important in recovering this water and preventing seawater intrusion. However, the analyses can be performed more effectively by numerical digital computer simulation.

Considerable ground water can be obtained from the north coast aquifers. Problems are apparent in some places but proper management of the water resources can relieve the situation, and water that is now being wasted to the sea can be salvaged. Effective management of the ground-water resources includes the gathering of appropriate data before serious problems arise.

Although basic hydrologic data are becoming available at an increasing rate in the area of industrial development, additional information on aquifer characteristics is needed. For instance, only single-well pumping tests of the water-table aquifer have been run and hence there is no basis for determining the storage coefficient or its areal variation. If largescale pumping is done in the area of the Caño Tiburones, additional observation we1ls must be installed to monitor the changes in drawdown and quality that may signal saltwater intrusion. 


\section{SELECTED REFERENCES}

Pennett, G.D., 1976, Flectrical analog simulation of the aquifers along the south coast of Puerto Rico: U.S. Geological. Survey Open-File Report $76-4,101 \mathrm{p}$.

Bennett, G.D., and Giusti, E.V., 1972, Ground water in the Tortuguero area, Puerto Rico, as related to proposed harbor construction: Puerto Rico Water-Resources Bulletin 10, $25 \mathrm{p}$.

Black and Veatch, 1976, Water supply study for the entire island of Puerto Rico, first phase: U.S. Army Engineer District, Jacksonville, Florida, $168 \mathrm{p}$.

Bosmaci, Yakup, and Sendlein, L.V., 1977, Model analysis of closed systems in karstic aquifers, in Hydrologic problems in karst regions: Western Kentucky University, Bowling Green, Kentucky, p. 202-213.

Briggs, R.P., 1961, Geology of Kewanee Interamerican 0il Company test well number 4CPR, northern Puerto Rico, in 0il and gas possibilities of northern Puerto Rico: Puerto Rico Mining Commission, 23 p.

Briggs, R.P., and Akers, J.P., 1965, Hydrogeologic map of Puerto Rico and adjacent islands: U.S. Geological Survey Hydrologic Investigations Atlas HA-197.

Brown, R.H., 1963, Estimating the transmissibility of an artesian aquifer, in Methods of determining permeability, transmissibility and drawdown: U.S. Geological Survey Water-Supply Paper 1536-I, p. 336-338.

Day, M.J., 1978, Morphology and distribution of residual limestone hills (mogotes) in the karst of northern Puerto Rico: Geological Society of America Bulletin, v. 89, March 1978, p. 426-432.

Díaz, J.R., 1973, Chemical quality of water in Caño Tiburones, Puerto Rico--a reconnaissance study carried out in 1967: U.S. Geological Survey, Puerto Rico Map Series No. 2, 2 pl. and drawdown: U.S. Geological Survey Water-Supply Paper 1536-I, p. 336-338.

Freeze, R.A., and Cherry, J.A., 1979, Ground water: Prentice-Hall, Englewood Cliffs, N.J., 604 p. Giusti, E.V., 1978, Hydrogeology of the karst of Puerto Rico: U.S. Geological Survey Professional Paper 1012, 68 p.

Giusti, E.V., and Bennett, G.D., 1976, Water resources of the north coast limestone area, Puerto Rico: U.S. Geological Survey Water-Resources Investigations $42-75,42 \mathrm{p}$.

Gómez, F.G., and Heisel, J.E., 1980, Summary Appraisals of the nation's ground- water resources caribbean Region: U.S. Geological Survey Professional Paper 813-U, p. 


\section{SELECTED REFERENCES-Continued}

Ivankovic, Tomislav, and Komatina, Miomir, 1976, Hydrogeologic estimation of ground-water storage connected with surface-water storage. Case of the Salakovac reservoir, in Karst hydrolcgy and water resources United States-Yugoslavian Symposium, Proceedings: Dubrovnjck, Yugoslavia, 1975, Water Resources Publications, Ft. Collins, Colorado, v. 1, p. 193-206.

LeGrand, H.E., Stringfield, V.T., and LaMoreaux, P.E., 1976, Hydrologic features of United States karst regions, in Karst hydrology and water resources, United States-Yugoslavian Symposium, Proceedings:

Dubrovnick, Yugoslavia, 1975, Water Resources Publications, Ft. Collins, Colorado, v. 1, p. 31-46.

Lohman, S.W., 1972, Ground water hydraulics: U.S. Geological Survey Professional Paper 708, 70 p.

McGuinness, C.L., 1946, Records of wells in Puerto Rico: Puerto Rico Aqueduct and Sewer Service in cooperation with U.S. Geological Survey, 267 p.

, 1948, Ground water resources of Puerto Rico: Puerto Rico Aqueduct and Sewer Service in cooperation with U.S. Geological Survey, 277 p.

Miotke, F.D., 1973, The subsidence of the surface between mogotes in Puerto Rico east of Arecibo, in Caves and karst, v. 15, no. 1, 12 p.

Monroe, W.H., 1976, The karst landforms of Puerto Rico: U.S. Geological Survey Professional Paper 899, 69 p.

1980, Geology of the middle Tertiary formations of Puerto Rico: U.S. Geological Survey Professional Paper 953, 93 p.

Morris, Greg, 1978, Ground water limitations in the Barceloneta area: Misión Industrial de Puerto Rico, Inc., Hato Rey, Puerto Rico, 32 p.

Parizek, R.R., 1976, On the nature and significance of fracture traces and lineaments in carbonate and other terranes, in Karst hydrology and water resources, United States-Yugoslavian Symposium, Proceedings: Dubrovnick, Yugoslavia, 1975, Water Resources Publications, Ft. Collins, Colorado, v.1 p. 47-109.

Quiñones-Márquez, Ferdinand, 1976, Chemical physical, biochemical and bacteriological determinations in Laguna Tortuguero, Puerto Rico, July 1974-June 1975: U.S. Geological Survey Open-File Report 76-5, 39 p.

Theis, C.V., 1963, Estimating the transmissivity of a water-table aquifer from the specific capacity of a well, in Methods of determining permeability, transmissibility and drawdown: U.S. Geological Survey Water-Supply Paper 1536-I, p. 332-336. 


\section{SELECTED REFERENCES-Continued}

Torbarov, Konstantin, 1976, Estimation of permeability and effective porosity in karst on the basis of recession curve analysis, in Karst hydrology and water resources, United States Yugoslavian Symposium Proceedings: Dubrovnick, Yugoslavia, 1975, Water Resources Publications, Ft. Collins, Colorado, v.1, p. 121-136.

Western Geophysical Company of America and Fugro, Inc., 1973, Geologicalgeophysical reconnaissance of Puerto Rico for siting of nuclear power plants: Puerto Rico Water Resources Authority, San Juan, Puerto Rico, $63 \mathrm{p}$.

Weston Geophysical Research, Inc. 1966, Geological and geophysical investigations of the proposed Tortuguero Nuclear Power Station for the Puerto Rico Water Resources Authority, San Juan, Puerto Rico, 98 p. 
